\title{
How Macrophages Become Transcriptionally Dysregulated: A Hidden Impact of Antitumor Therapy
}

\author{
Galina F. Medvedeva ${ }^{1, \dagger}$, Daria O. Kuzmina ${ }^{1, \dagger}$, Julia Nuzhina ${ }^{2}{ }^{(0)}$, Alexander A. Shtil ${ }^{1,2}$ and \\ Marina S. Dukhinova ${ }^{1, *}$ \\ 1 International Institute 'Solution Chemistry of Advanced Materials and Technologies', ITMO University, \\ 191002 Saint-Petersburg, Russia; medvedeva@scamt-itmo.ru (G.F.M.); kuzmina@scamt-itmo.ru (D.O.K.); \\ shtil@scamt-itmo.ru (A.A.S.) \\ 2 Institute of Gene Biology, Russian Academy of Science, 119334 Moscow, Russia; julia.nuzhina@gmail.com \\ * Correspondence: marina.dukhinova@gmail.com \\ + Authors contributed equally.
}

Citation: Medvedeva, G.F.; Kuzmina, D.O.; Nuzhina, J.; Shtil, A.A.;

Dukhinova, M.S. How Macrophages Become Transcriptionally Dysregulated: A Hidden Impact of Antitumor Therapy. Int. J. Mol. Sci. 2021, 22, 2662. https://doi.org/ $10.3390 /$ ijms 22052662

Academic Editor: Tzong-Shyuan Lee

Received: 1 February 2021

Accepted: 1 March 2021

Published: 6 March 2021

Publisher's Note: MDPI stays neutral with regard to jurisdictional claims in published maps and institutional affiliations.

Copyright: (c) 2021 by the authors. Licensee MDPI, Basel, Switzerland. This article is an open access article distributed under the terms and conditions of the Creative Commons Attribution (CC BY) license (https:/ / creativecommons.org/licenses/by/ $4.0 /)$.

\begin{abstract}
Tumor-associated macrophages (TAMs) are the essential components of the tumor microenvironment. TAMs originate from blood monocytes and undergo pro- or anti-inflammatory polarization during their life span within the tumor. The balance between macrophage functional populations and the efficacy of their antitumor activities rely on the transcription factors such as STAT1, NF- $\mathrm{kB}$, IRF, and others. These molecular tools are of primary importance, as they contribute to the tumor adaptations and resistance to radio- and chemotherapy and can become important biomarkers for theranostics. Herein, we describe the major transcriptional mechanisms specific for TAM, as well as how radio- and chemotherapy can impact gene transcription and functionality of macrophages, and what are the consequences of the TAM-tumor cooperation.
\end{abstract}

Keywords: tumor-associated macrophages; transcription factors; cancer; immunotherapy; radiotherapy; chemotherapy; oncoimmunology

\section{Introduction}

Tumor-associated macrophages (TAMs) are essential components of the tumor microenvironment, along with other immune cells, fibroblasts, and neovasculature [1,2]. Macrophages, including TAMs, interact with the surrounding milieu and exhibit functional diversity with the specific release of pro- and anti-inflammatory cytokines and growth factors [3-8]. TAMs represent a mixed cell population, which includes pro- and antiinflammatory activated macrophages and newly infiltrated macrophages and monocytes that migrate from the surrounding tissues or through the blood vessel wall, respectively, and undergo further alterations in the tumor microenvironment. Of interest, phenotypically and functionally, TAMs are more similar to tissue-resident cells, such as alveolar macrophages (lungs), Kupffer cells (liver), microglia (the central nervous system), and others, depending on the tumor location, but not to blood-derived monocytes.

Generally, macrophages are classified as resting (non-activated, M0), proinflammatory (classically activated, M1), or anti-inflammatory (alternatively activated, M2) [9]. Tumor microenvironment contains a plethora of signaling and chemoattractant molecules, which flexibly balance the monocyte/macrophage pro- or anti-inflammatory polarization (Tables 1 and 2). M1 activation is induced in response to Toll-like receptor (TLR) ligands such as bacterial lipopolysaccharide (LPS) and lipoteichoic acid, or proinflammatory cytokines such as tumor necrosis factor alpha (TNF- $\alpha$ ) and interferon gamma (IFN- $\gamma$ ) [10]. The major M1-associated transcriptional patterns require the participation of nuclear factor kappa-light-chain-enhancer of activated B cells (NF- $\mathrm{kB}$ ) and signal transducer and activator of transcription 1 (STAT1) in cooperation with interferon regulatory factor (IRF) 9, p53, and other transcription factors (TFs) (Table 1) [11,12]. M1-like macrophages show a high 
capacity for antigen presentation and increased production of nitric oxide (NO), reactive oxygen species (ROS), and proinflammatory cytokines (interleukin (IL) IL-1 $\beta$, IL-6, tumor necrosis factor alpha (TNF- $\alpha$ ), and others), playing a dual role in the tumor microenvironment $[13,14]$. Proinflammatory activity improves the therapeutic outcome in patients with breast, ovarian, lung, and other types of cancer [3-5]. At the same time, M1-like macrophages stimulate cancer cell motility and are associated with tumor progression in certain cases, such as pancreatic and gastric cancer $[8,15,16]$. Cytokines, such as IL-4, IL-6, IL-10, IL-13, chemokine (C-C motif) ligand (CCL) 2, TNF- $\alpha$, transforming growth factor beta (TGF- $\beta$ ), or prostaglandin E2 (PGE2), functionalize anti-inflammatory macrophage polarization, thereby suppressing immunity and stimulating angiogenesis, tissue remodeling/repair, and self-antigen tolerance [17-21]. Anti-inflammatory polarization requires activation of STAT3, STAT6, and NF-kB p50-p50 homodimer (Table 2) [22,23]. M2-like cells release cytokines IL-4, IL-10, IL-13, and growth factors TGF- $\beta$, vascular endothelial growth factor (VEGF), epidermal growth factor (EGF), which exhibit pro-tumorigenic properties: stimulate cell proliferation, tumor encapsulation, and vasculogenesis and promote drug resistance $[6,7]$.

Table 1. Major transcription factors involved in proinflammatory macrophage polarization.

\begin{tabular}{|c|c|c|c|}
\hline $\begin{array}{l}\text { Transcription } \\
\text { Factor }\end{array}$ & Activating or Inhibitory Stimuli & Target Genes (Up/Down Regulated) & Reference \\
\hline \multirow[t]{4}{*}{ NF-KB } & Hypoxia $\uparrow$ & Up: HIF1A, COX2 & [24] \\
\hline & LPS $\uparrow$ & Up: ADM, HIF1A, COX2, INOS, TNFA, IL6 & [25-27] \\
\hline & Fungal polysaccharide $\uparrow$ & Up: INOS, IL6, TNFA, COX2 & [28] \\
\hline & Mechanical stretch $\uparrow$ & Up: INOS, TNFA, IL1B, IL6 & [29] \\
\hline \multirow{2}{*}{ STAT1 } & IFN- $\gamma \uparrow$ & Up: GBP6, CXCL10, CIITA, IRF1, CXCL11, IFIT2 & {$[30,31]$} \\
\hline & $\mathrm{HDL} \uparrow$ & Up: IL12B & [32] \\
\hline STAT3 & LPS $\uparrow$ & Up: IL8 and TNFA & [33] \\
\hline \multirow{3}{*}{ IRF1 } & GM-CSF + IFN- $\gamma \uparrow$ & Up: INOS & [34] \\
\hline & IFN- $\gamma \uparrow$ & Up: IL12B, IL6, TNFA & {$[35,36]$} \\
\hline & IFN- $\alpha \uparrow$ & $\begin{array}{c}\text { Down: IL10 } \\
\text { Un. IL12B }\end{array}$ & \\
\hline IRF2 & LPS $\uparrow$ & $\begin{array}{l}\text { Up: IL12B, IL12Rb1, IFNG, IL1B, IL6 } \\
\text { Down: TNFA }\end{array}$ & [37] \\
\hline IRF3 & $\operatorname{LPS} \uparrow$ & Up: IFNB1 & [38] \\
\hline IRF5 & $\mathrm{IFN}-\gamma+\mathrm{LPS} / \mathrm{GM}-\mathrm{CSF} \uparrow$ & $\begin{array}{l}\text { Up: IL12B, IL23 } \\
\text { Down: IL10 }\end{array}$ & [39] \\
\hline IRF6 & $\mathrm{IL}-4 \downarrow$ & Up: ARG1, IL10, PPARG & [40] \\
\hline IRF7 & IFN- $\alpha$, LPS $\uparrow$ & Down: IL10 & {$[41,42]$} \\
\hline IRF8 & IFN- $\gamma \uparrow$ & Up: TNFA & [43] \\
\hline
\end{tabular}


Table 2. Major transcription factors involved in anti-inflammatory macrophage polarization.

\begin{tabular}{|c|c|c|c|}
\hline Transcription Factor & Activating or Inhibitory Stimuli & Target Genes (Up/Down Regulated) & Reference \\
\hline NF- $k B$ & $\mathrm{IL}-17 \uparrow$ & Up: ARG1, FIZZ1, YM1, CD206, CD163 & {$[44]$} \\
\hline & $\mathrm{IL}-10 \uparrow$ & Down: IL12B & [45] \\
\hline & GDF-15 $\uparrow$ & Down: INOS, TNFA & [46] \\
\hline STAT3 & $\begin{array}{c}\text { IL-6 + LIF } / \text { ERK5 } \uparrow \\
\text { IL-6 } \uparrow\end{array}$ & $\begin{array}{c}\text { Up: ARG1, VEGFA, } \\
\text { TGFB1 and IL10 } \\
\text { Down: IL12B, INOS, TNFA } \\
\text { Up: ARG1, FIZZ1, IL10 }\end{array}$ & {$[47,48]$} \\
\hline STAT6 & IL-4, IL-13个 & Up: FN1, CCL22 & [49] \\
\hline STAT5 & IL-6 $\uparrow$ & Up: PDCD1LG2, CYP19A1 & [50] \\
\hline IRF4 & LPS $\uparrow$ & Down: TNFA, IL12B & {$[51]$} \\
\hline p53 & $\mathrm{IL}-4 \downarrow$ & Up: MYC, ARG1, FIZZ1 & [52] \\
\hline
\end{tabular}

Legend and abbreviations used in Tables 1 and 2. The major transcription factors involved in pro-(Table 1) and anti- (Table 2) inflammatory polarization. Transcription factors (column 1) become activated following specific external stimuli (column 2), regulate certain gene expression (column 3), and participate in macrophage functional polarization. $\uparrow$-activating stimulus; $\downarrow$-inhibitory stimulus; up - regulated genes; down—down-regulated genes. NF-kB — nuclear factor kappa-light-chain-enhancer of activated B cells; STAT—signal transducer and activator of transcription; IRF-interferon regulatory factors; LPS-lipopolysaccharide; IFN- $\alpha$-interferon alfa; IFN- $\gamma$-interferon gamma; HDL-high-density lipoprotein; GM-CSF-granulocyte-macrophage colony-stimulating factor; IL-interleukin; GDF-15-growth differentiation factor 15; LIF-leukemia inhibitory factor; HIF1A — hypoxia-inducible factor 1-alpha; COX2-prostaglandin-endoperoxide synthase 2; ADM —-adrenomedullin; INOS—inducible nitric oxide synthase; TNFA—tumor necrosis factor; ARG1—arginase-1; CD—cluster of differentiation; TGFB1 - transforming growth factor beta; GBP6 - guanylate binding protein; CXCL-C-X-C motif chemokine ligand; CIITA-class II major histocompatibility complex transactivator; IFIT2-interferon-induced protein with tetratricopeptide repeats 2; IFNB1-interferon beta 1; IFNG—interferon gamma; PPARG—peroxisome proliferator-activated receptor gamma; VEGFA—vascular endothelial growth factor A; FN1—fibronectin 1; CCL22-C-C motif chemokine ligand 22; PDCD1LG2—programmed cell death 1 ligand 2; CYP19A1—cytochrome P450 family 19 subfamily A member 1.

Additionally, the M1/M2 ratio and the exact cytokine secretion profile of macrophages vary with respect to cancer stage and tumor microenvironment [53,54]. With the disease progression, the number of M2-like TAMs gradually increases in the tumor microenvironment due to its immunosuppressive activities and abnormal blood vessel fenestration, as it is shown for lung carcinoma, cutaneous melanoma, colorectal, prostate, and ovarian cancer [55-59]. Moreover, the transition from acute to chronic inflammation, which occurs at the late stages, reduces antitumor immunoreactivity and increases growth factor production with subsequent tumor growth and metastasis [60,61].

The pro- or anti-oncogenic function of macrophages is precisely controlled by the specific TFs, which can be used as additional diagnostic and immunotherapeutic tools (Figure 1) $[13,62,63]$.

TF activities depend on the disease stage and therapeutic regimen. However, transcriptional programming of macrophages during chemo- and radiotherapy is not fully investigated. In this review, we focus on the role of TAMs in cancer therapy. We address the transcriptional mechanisms of macrophage polarization in response to chemotherapy or ionizing radiation and the routes for macrophages-supported immunotherapy to improve the outcome of the disease. 


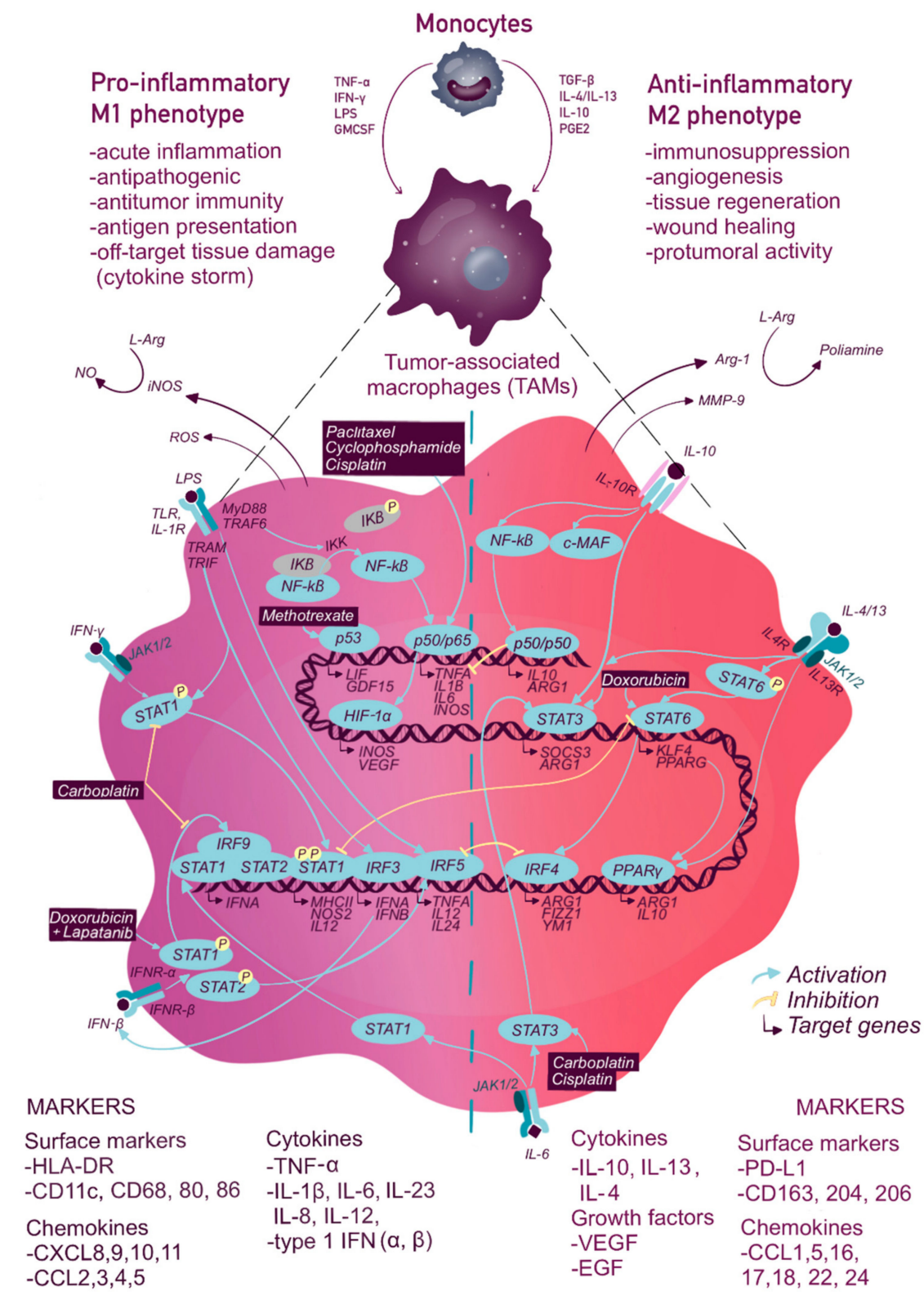

Figure 1. Transcription factors involved in macrophage polarization: impact of tumor microenvironment and chemotherapy. The activation or inhibition of signaling pathways are indicated by the blue arrows or by the yellow suppression symbols, respectively. The principal chemotherapeutic drugs, which impact macrophage transcriptional profiles, are shown. TAMs transcriptional patterns require phosphorylation $(\mathrm{P})$ and activation of NF-kB, STATs, IRFs, p53, and other TFs (Table 1) [11,12]. NF-KB (P65-p50 heterodimer) becomes activated upon LPS stimulation and acts as a positive regulator of proinflammatory gene transcription in macrophages [28,45,64-66]. However, anti-inflammatory macrophage activity is also

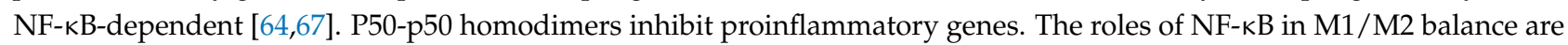
likely associated with p65/p50 ratio [68-70]. Hypoxia-inducible factor 1-alpha (HIF-1 $\alpha$ ) and p53 are also associated with the proinflammatory macrophage phenotype [24,52,71-74]. IRF3 and 5 are involved in proinflammatory macrophage polarization following IFN- $\alpha / \beta$ (interferon alfa/beta) and IFN- $\gamma$ receptor engagement while IRF4 is involved in IL-4-induced macrophage polarization $[65,75,76]$. TLR and IFN $-\gamma$ receptor signaling induces macrophage proinflammatory activity with STAT1-dependent increase in NOS2, IL12, MHC (major histocompatibility complex) class II expression and enhanced antigen presentation [31]. IL-4 and IL-13 induce alternative polarization implying TFs STAT3 and STAT6 [77-80]. M1-like macrophages show increased production of NO, ROS, and proinflammatory cytokines IL-1 $\beta$, IL-6, TNF- $\alpha$, and others [13,14]. M2-like cells release cytokines IL-4, IL-10, IL-13, and growth factors TGF- $\beta$, VEGF, EGF that exhibit pro-tumorigenic properties [6,7]. Chemotherapeutic agents such as paclitaxel, cyclophosphamide, and cisplatin induce M1 polarization via NF-кB (p50/p65) [4,81-84]. Cisplatin and carboplatin alter M2 differentiation via STAT3, while carboplatin suppresses STAT1 and STAT6 $[85,86]$. Doxorubicin in combination with lapatinib activates immature macrophages via STAT1 [87]. 


\section{Macrophage Transcriptional Reprogramming during Chemo- and Radiotherapy}

Tumor resistance relies directly on the interaction between cancer cells and their surrounding $[6,88]$. TAMs are among the major tumor microenvironment components, which significantly restrict therapeutic efficiency and mediate tumor resistance via several essential mechanisms. First, macrophages stimulate drug metabolism and removal from the cancer cell [89]. Second, tumorigenic cytokines, such as IL-6, insulin-like growth factors (IGF) 1 and 2, produced by TAMs, also promote drug resistance in various cancer types [90-92]. Finally, M2-like macrophages tend to accumulate in proximity to the tumor blood vessels following therapy and release the plethora of growth factors, leading to revascularization and tumor relapse [93]. Given that, the TAM functionality is a major factor that determines the treatment outcome (Table 3).

Table 3. Effects of chemotherapy and radiotherapy on macrophage phenotypes.

\begin{tabular}{|c|c|c|c|}
\hline $\begin{array}{l}\text { Therapeutic } \\
\text { Intervention }\end{array}$ & Tumor Type & Mechanism of Action & Impact on Macrophages \\
\hline Doxorubicin & $\begin{array}{l}\text { Breast, bladder carcinoma, } \\
\text { Kaposi sarcoma, lymphoma, } \\
\text { acute lymphocytic } \\
\text { leukemia [94-98] }\end{array}$ & $\begin{array}{l}\text { - Intercalates within DNA base pair; } \\
\text { - } \quad \text { Inhibits DNA and RNA synthesis; } \\
\text { - } \quad \text { Inhibits topoisomerase II causing } \\
\text { DNA damage and induction of } \\
\text { apoptosis [99] }\end{array}$ & $\begin{array}{l}\text { - In combination with lapatinib: suppresses TAMs, } \\
\text { activates immature macrophages via STAT1 and recruits } \\
\text { them to the tumor site [87]; } \\
\text { - In combination with cyclophosphamide, vincristine and } \\
\text { immunotherapy induces M1 polarization [81]; } \\
\text { - Induces M2 polarization via JAK2/STAT3 pathway, } \\
\text { stimulates CD206, and decreases iNOS production [77]; } \\
\text { - Induces M2 polarization via STAT6, up-regulates IL10 and } \\
\text { TGFB1 expression [100] }\end{array}$ \\
\hline Taxol (Paclitaxel) & $\begin{array}{l}\text { Ovarian, breast, lung, sarcoma } \\
\text { Kaposi, cervix, } \\
\text { pancreas [101-105] }\end{array}$ & $\begin{array}{l}\text { - Stimulates tubulin polymerization, } \\
\text { anti-mitotic and proapoptotic } \\
\text { activity [106] }\end{array}$ & $\begin{array}{l}\text { - Induces M1 polarization via NF- } \kappa B \text { (p50/RelA and } \\
\text { p50/c-Rel) and IRF; } \\
\text { - } \quad \text { Stimulates TNF- } \alpha \text { and IL-12 production }[4,82]\end{array}$ \\
\hline $\begin{array}{l}\text { Cyclophosphamide } \\
\text { (CY) }\end{array}$ & $\begin{array}{l}\text { Hodgkin, non-Hodgkin, } \\
\text { cutaneous T-cell } \\
\text { lymacrophageomas, multiple } \\
\text { myeloma, leukemia, } \\
\text { retinoblastoma, neuroblastoma, } \\
\text { ovarian cancer, breast } \\
\text { cancer [107-114] }\end{array}$ & $\begin{array}{l}\text { - } \\
\text { - Decreases the IFN- } \gamma \text { and } \\
\text { IL-12 production; } \\
\text { - } \quad \text { Increases Th2 cytokine (IL-4, IL-10) } \\
\text { levels in the cerebrospinal fluid and } \\
\text { peripheral blood; } \\
\text { - Shows immunosuppressive } \\
\text { activity }[115,116]\end{array}$ & $\begin{array}{l}\text { - } \quad \text { Activates NF- } \kappa B \text {; } \\
\text { Stimulates the production of proinflammatory IL-6 and } \\
\text { IL-12 cytokines and decreases anti-inflammatory IL-10 } \\
\text { and TGF- } \beta \text { production [83]; } \\
\text { - Increases the number of M1 TAMs in a mouse model [81] }\end{array}$ \\
\hline Cisplatin & $\begin{array}{l}\text { Testicular, ovarian, cervical, } \\
\text { breast, bladder, head and neck, } \\
\text { esophageal, lung, } \\
\text { mesothelioma, } \\
\text { neuroblastoma [117-122] }\end{array}$ & $\begin{array}{l}\text { - Interacts with DNA forming } \\
\text { crosslink adducts; } \\
\text { - Activates pro-apoptotic signaling } \\
\text { pathways [123] }\end{array}$ & $\begin{array}{l}\text { - Modulates M1 TAM phenotype and stimulates iNOS, } \\
\text { TNF- } \alpha \text {, IL-1 } \beta \text {, IL-12, and IFN- } \gamma \text { production [124,125]; } \\
\text { - } \text { Alters M2 differentiation via STAT3, stimulates IL-10, } \\
\text { IL-12 production [85] }\end{array}$ \\
\hline Carboplatin & $\begin{array}{l}\text { Ovarian, lung, head and neck, } \\
\text { endometrial, esophageal, } \\
\text { bladder, breast, cervical } \\
\text { cancers; central nervous system } \\
\text { or germ cell tumors; osteogenic } \\
\text { sarcoma [126-132] }\end{array}$ & $\begin{array}{l}\text { - Forms reactive platinum complexes; } \\
\text { - Forms the cross-linked adducts of } \\
\text { DNA molecules; } \\
\text { - inhibits DNA synthesis in all the } \\
\text { phases of the cell cycle [133] }\end{array}$ & $\begin{array}{l}\text { - Induces M2-like phenotype via STAT3 activation, STAT1 } \\
\text { and STAT6 suppression, IL-10, IL-12 stimulation }[85,86]\end{array}$ \\
\hline Methotrexate & $\begin{array}{l}\text { Cervical, breast, lung, head and } \\
\text { neck, lymacrophageoma, } \\
\text { leukemia [134-138] }\end{array}$ & $\begin{array}{l}\text { - Inhibits dihydrofolate reductase } \\
\text { (DHFR) and nucleotide } \\
\text { biosynthesis [139] }\end{array}$ & $\begin{array}{l}\text { - Induces p53 activity in TAMs; contributes to the } \\
\text { thymidylate synthase-dependent drug sensitivity [140] }\end{array}$ \\
\hline Olaparib & $\begin{array}{l}\text { Prostate, pancreatic, and breast } \\
\text { cancer [141-143] }\end{array}$ & $\begin{array}{l}\text { - Inhibits poly (ADP-ribose) } \\
\text { polymerase (PARP) responsible for } \\
\text { DNA break repair; } \\
\text { - Leads to cancer cell apoptosis, } \\
\text { especially during homologous } \\
\text { recombination [144] }\end{array}$ & - Induces M1 polarization via IRF5 [145] \\
\hline
\end{tabular}


Table 3. Cont.

\begin{tabular}{|c|c|c|c|}
\hline $\begin{array}{l}\text { Therapeutic } \\
\text { Intervention }\end{array}$ & Tumor Type & Mechanism of Action & Impact on Macrophages \\
\hline \multicolumn{4}{|c|}{ Radiotherapy, dose } \\
\hline 2 Gy & Rectal cancer [145] & $\begin{array}{l}\text { - } \quad \text { DNA double- and single-strand breaks; } \\
\text { - } \text { ROS generation; } \\
\text { - } \\
\text { Activates cell repair following DNA } \\
\text { damage }[146,147]\end{array}$ & $\begin{array}{l}\text { - Activates IRF TF and up-regulates TNFA, IFNG, IL6, IL8, } \\
\text { and IL23 expression; } \\
\text { - Induces M1 polarization via IRF5 activation }\end{array}$ \\
\hline 10 Gy & Colon carcinoma [148] & $\begin{array}{l}\text { Recruits ATM and activates Chk2 for } \\
\text { DNA repair and checkpoint } \\
\text { escape }[146,147]\end{array}$ & $\begin{array}{l}\text { - Triggers RelB nuclear translocation and expression; } \\
\text { - Stimulates Bcl-xL production and promotes } \\
\text { TAM survival; } \\
\text { - Stimulates IL-10, IL-6, CCL2 production and up-regulates } \\
\text { HLA-DR, CD80, and CD86 cell membrane expression; } \\
\text { - Induces M1 polarization }\end{array}$ \\
\hline 12-13.3 Gy & $\begin{array}{l}\text { Melanoma [149] } \\
\text { Lung cancer [150] } \\
\text { Pancreatic ductal } \\
\text { adenocarcinoma [151] }\end{array}$ & $\begin{array}{l}\text { - Induces HMGB1 production by } \\
\text { tumor and subsequent macrophage } \\
\text { remodeling [152] }\end{array}$ & $\begin{array}{l}\text { - } \quad \text { Activates TFs STAT3, STAT6, SOCS3 and suppresses IRF5; } \\
\text { - } \quad \text { Stimulates CCL2, HDC, TGF- } \beta \text {, IL-6, IL-6R, IL-23, IL-13, } \\
\text { Arg- } 1 \text { and IL- } 12 \text { and IFN- } \gamma \text { production; } \\
\text { - } \quad \text { Polarizes macrophages towards M2 }\end{array}$ \\
\hline 20 Gy & Breast cancer [153] & $\begin{array}{l}\text { - Induces tumor antigens and } \\
\text { endogenous adjuvants production } \\
\text { (heat shock proteins) and subsequent } \\
\text { macrophage remodeling }[154,155]\end{array}$ & $\begin{array}{ll}\text { - } & \text { Stimulates p50 activity; } \\
\text { - } & \text { Increases Arg-1 and IL-10 production; } \\
\text { - } & \text { Induces M2 polarization via p50 activation }\end{array}$ \\
\hline 1.5 Gy X-ray & Lung cancer [156] & $\begin{array}{l}\text { - Decreases TGF- } \beta \text { production in the } \\
\text { tumor microenvironment [157] }\end{array}$ & $\begin{array}{l}\text { - } \quad \text { Suppresses STAT6; } \\
\text { - } \quad \text { Promotes M1 polarization }\end{array}$ \\
\hline $\begin{array}{l}66-70 \text { Gy total in } \\
2-2.2 \text { Gy fractions }\end{array}$ & Head and neck cancers [158] & $\begin{array}{l}\text { - Induces tumor-derived } \\
\text { mitochondrial DNA production, } \\
\text { TLR9 signaling, and macrophage } \\
\text { remodeling [159] }\end{array}$ & $\begin{array}{l}\text { - Implies STAT3 transcriptional activity; } \\
\text { - } \quad \text { Up-regulates ARG1, LIF, TGFB1, IL4 and IL5 expression } \\
\text { in TAMs; } \\
\text { - Induces M2 polarization }\end{array}$ \\
\hline $8 \mathrm{~Gy}$ & $\begin{array}{l}\text { Pancreatic ductal } \\
\text { adenocarcinoma [160] }\end{array}$ & $\begin{array}{l}\text { - Stimulates TGF- } \beta \text { production in the } \\
\text { tumor microenvironment [161] }\end{array}$ & $\begin{array}{ll}\text { - } & \text { Activates STAT3; } \\
\text { - } & \text { Stimulates CCL2, CCL4, VEGF, and TGF- } \beta \text { production; } \\
\text { - } & \text { Induces M2 polarization }\end{array}$ \\
\hline $\begin{array}{l}5-10 \text { Gy proton } \\
\text { irradiation }\end{array}$ & Lung adenocarcinoma [68] & $\begin{array}{l}\text { - Induces ATM recruitment and } \\
\text { DNA repair }\end{array}$ & $\begin{array}{l}\text { - Promotes p65 nuclear translocation; } \\
\text { - Induces M1 polarization }\end{array}$ \\
\hline
\end{tabular}

Legend and abbreviations used in Table 3. Treatment (column 1) strategies applied for majority of cancer types (column 2) induce principal alterations in cancer and tumor-associated cells impacting cell survival and metabolism (column 3 ). The therapeutic interventions additionally exhibit pro- or anti-inflammatory effects mediated by macrophages (column 4). Gy—Gray (Units); $\gamma$-gamma-irradiation; DNA—deoxyribonucleic acid; RNA—ribonucleic acid; Th2—T helper cell 2; ADP—ribose-adenosine diphosphate ribose; ROS-reactive oxygen species; ATM—ataxia telangiectasia mutated; Chk2—checkpoint kinase 2; HMGB1—high-mobility group protein B1; TLR9— toll-like receptor 9; JAK2-janus kinase 2; RelA, Bcl-xL-B-cell lymphoma-extra large; HLA-DR - human leukocyte antigen-DR isotype; SOCS3 - suppressor of cytokine signaling 3; HDC—-histidine decarboxylase; iNOS-inducible nitric oxide synthase; TNF- $\alpha$-tumor necrosis factor alpha; TGF- $\beta$ — transforming growth factor beta; Arg-1—arginase-1.

While therapeutic responses are modulated by TAMs, chemo- and radiotherapy also show direct and indirect effects on macrophage survival and activity. The direct action is associated with the off-target cytotoxicity and pro- or anti-inflammatory activation of macrophages. The majority of TAMs are polarized to M2-like phenotype and can release numerous tumor-promoting factors before the treatment. Radio- or chemotherapy can prevent these undesired events reducing M2 macrophage numbers and attracting the bloodderived monocytes with the higher anti-tumor potential. The monocyte infiltration and proinflammatory signaling are supported via pro-inflammatory cytokines and chemokines (ex., CCL2) from the tumor microenvironment (Figures 1 and 2) increased blood vessel wall permeability and signaling from dead and damaged cancer cells $[87,162]$.

The indirect mechanisms are caused by the incoming signals from (a) the damaged, dying, and, at the later time points, resistant cancer cells and (b) the altered tumor microenvironment. Upon chemical and irradiation exposure, surviving cancer cells produce pro-tumor cytokines as IL-17, stromal cell-derived factor-1 (SDF-1), CCL2, and colonystimulating factor 1 (CSF-1), which limit the therapeutic benefits [44,163-165]. At the same time, cancer cell damage and ROS generation induce proinflammatory macrophage activities, as phagocytosis, antigen presentation, and production of proinflammatory factors such as inducible nitric oxide synthase (iNOS) and TNF- $\alpha$, and lymphocyte chemoattraction $[85,124,125,166-168]$. With that, the therapeutic impact on TAMs remains controversial with possible pro- or anti-inflammatory polarization and hardly predictable outcomes. 
As macrophage polarization and cytokine production rely on the cell transcriptional machinery, we aim to discuss the major TFs involved in cytokine network regulation-NF- $\mathrm{kB}$, STAT-family, IRF-family, and p53,-in the context of the tumor microenvironment and chemo- and radiotherapy (Figures 1 and 2, Table 3).

\section{Pro-inflammatory M1 phenotype}

\section{Tumor-associated macrophages (TAMs)}

\section{Anti-inflammatory M2 phenotype}

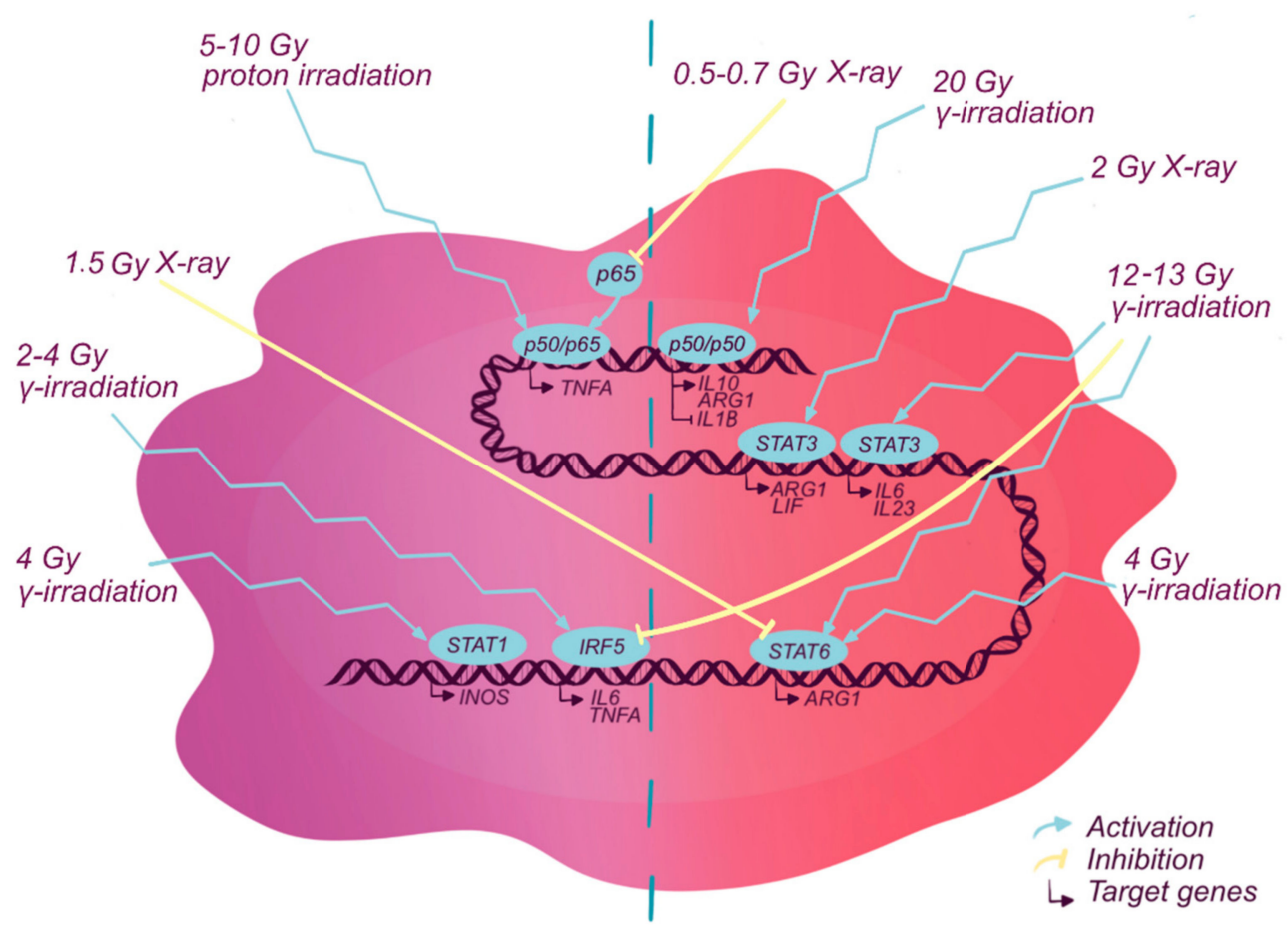

Figure 2. Transcriptional activity of tumor-associated macrophages during radiotherapy. The activation or inhibition of signaling pathways are indicated by the blue arrows or by the yellow suppression symbols, respectively. Gy-Gray (Units). The most common types of radiotherapy applied in clinics are gamma $(\gamma)^{-}$, proton-, and X-ray irradiation (Figure 2). Irradiation doses range from low (less than $1 \mathrm{~Gy})$ and moderate (2-10 Gy) to high (>10 Gy) and can be applied as a single course or fractionated [169-171]. G -irradiation (2 Gy) induces M1 phenotype via IRF5 activation [145]. Bigger doses (>12 Gy) induce M2 phenotype via STAT3 and STAT6 activation with IRF5 suppression and p50-p50 activation, respectively [149-151,153]. Four Gy $\gamma$-irradiation activates STAT1 and STAT6, up-regulates M1 and M2 markers [172]. 1.5 Gy X-ray induces macrophage polarization toward M1 phenotype via STAT6 suppression while 5-10 Gy proton irradiation induces M1 phenotype via p50-p65 nuclear translocation [68,156]. Two or eight Gy X-ray induce M2 phenotype via STAT3 activation while 0.5-0.7 Gy X-ray down-regulates M1 markers via inhibition of p65 nuclear transport $[158,160,173]$.

\subsection{The Nuclear Factor Kappa B (NF- $\kappa b)$}

The NF-kB/Rel TF family in mammals consists of five proteins-p65 (Rel-A, transcription factor p65), p50 (NF-kB1, nuclear factor NF-kappa-B p105 subunit), p52 (NF-kB2, nuclear factor NF-kappa-B p100 subunit), c-Rel (proto-oncogene c-Rel), and RelB (transcription factor RelB), with possible 15 combinations of homo- and heterodimeric complexes. All of these proteins contain a characteristic N-terminal Rel homology domain (RHD) required for dimerization and target DNA binding [174]. NF- $\mathrm{B}$ participates in cell metabolism and is also involved in responses to external stimuli such as cytokines, ROS, heavy metals, irradiation, bacterial, and viral infection. Additionally, NF- $\mathrm{kB}$ is a well-known mediator of tumor-associated inflammation [175,176].

The reported roles for NF- $\mathrm{kB}$ in TAMs are associated with both pro- and anti-inflammatory functions [64]. It is well-known that NF-kB transcription is driven upon LPS stimulation and results in proinflammatory cytokine production (Table 1 ) $[28,45,65,66]$. NF- $\mathrm{B} B$ 
signaling is inhibited in M2-like TAMs in many tumors including glioblastoma, ovarian cancer, hepatocellular carcinoma, and others $[176,177]$. At the same time, macrophage anti-inflammatory activity is also controlled by NF- $\mathrm{kB}[64,67]$. NF- $\mathrm{kB}$ p50 and p65 subunits are both embedded into M2-like polarization with high IL-10 and low IL-12 secretion profiles [44,178-180]. The roles of NF- $\mathrm{kB}$ in M1/M2 balance are likely associated with a p65/p50 ratio with p65-p50 heterodimers supporting proinflammatory functions and p50 homodimers acting as anti-inflammatory mediators [68-70]. NF- $\mathrm{kB}$ functionality is essential for TAM transcriptional reprogramming and prediction of the outcome for chemo-, radio, and immunotherapy.

\subsubsection{NF- $\mathrm{kB}$ and Chemotherapy}

Numerous drugs impact NF- $\mathrm{kB}$ transcriptional activity guiding TAMs toward M1 polarization. Taxol, cyclophosphamide, and cisplatin stimulate NF-kB p50/RelA and p50/c-Rel subunits and upregulate proinflammatory cytokine (TNFA, IL12, INOS, COX2) and TLR gene expression while downregulating anti-inflammatory IL10 and TGFB (Figure 1) [82-84,107]. Interestingly, combinations of cyclophosphamide, vincristine, and doxorubicin with immunotherapy induce only partial M1-activation of TAMs [81].

NF- $\mathrm{KB}$ plays a critical role not only in macrophage polarization but also in their metabolism and surveillance in the tumor microenvironment upon chemotherapy. Such effects of chemotherapy are mediated via caspase-8-dependent apoptosis, which is selectively activated in monocytes and tumor-associated phagocytes upon trabectedin treatment and in M2-like TAMs upon platinum-containing drug exposure) [85,181-184]. Upon chemotherapy, NF- $\mathrm{KB}$ acts as an important proinflammatory inductor and regulator of macrophage viability.

\subsubsection{NF- $\kappa$ B and Radiotherapy}

Radiotherapy can shift the balance between NF- $\mathrm{kB}$ subunits depending on the irradiation dose (Figure 2). Low radiation doses increase the nuclear translocation of p50-p50 homodimer and inhibit p65 translocation, thereby reducing IL1B expression and proinflammatory macrophage activity [173]. Moderate doses (5-10 Gy) preferentially stimulate p65-p50 transcriptional activity in macrophage thereby reprogramming them into M1 phenotype with increased TNF- $\alpha$, IL-6, IL-8 and reduced EGF [68]. High irradiation dose utilizes p50 subunit for M2 polarization and maintenance of the immunosuppressive microenvironment following radiotherapy [153]. NF- $\mathrm{kB}$ mediates pro-survival signaling in macrophages exposed to $10 \mathrm{~Gy}$ and higher cumulative doses [148]. This mechanism partially protects macrophages from irradiation. The preferred strategy for NF- $\mathrm{kB}$ implementation in radiotherapy is to target p50/p65 and to consider the doses of irradiation.

\subsection{STAT Transcription Factor Family}

The STAT family consists of 7 TFs including STAT1, STAT3, STAT6, which play an essential role in macrophage polarization. TLR and IFN- $\gamma$ receptor signaling induces macrophage proinflammatory activity with STAT1-dependent increase in NOS2, IL12, MHC (major histocompatibility complex) class II expression and enhanced antigen presentation [31]. IL-4 and IL-13 induce alternative polarization with high levels of IL-10 and Arg-1 (Arginase-1), implying TFs STAT3 and STAT6 [77-80]. STAT3 can also orchestrate NF-KB-mediated transcription and promote pro-tumor chronic inflammation [33,185-187].

\subsubsection{STATs and Chemotherapy}

Chemotherapy has a strong impact on macrophage STAT activities resulting in TAM abundance and phenotypic alterations. Among the routinely applied anticancer drugs, cisplatin and carboplatin increase STAT3 and STAT6 activity and M2-like phenotype of the TAMs [85]. Doxorubicin treatment alone stimulates STAT6 and is also associated with anti-inflammatory effects. At the same time, combined therapy with doxorubicin and cyclophosphamide or EGFR inhibitor lapatinib implies M1-associated STAT1 to stimu- 
late and prolong macrophage antitumor activity [87]. Imatinib and paclitaxel inhibit the STAT6 pathway and M2-like cytokine production in macrophages showing, thus, proinflammatory potential $[4,188]$. Taken together, STAT TFs exhibit multidirectional effects in TAM functionality due to counterplay between the various STAT members, NF- $\mathrm{kB}$, and other TFs.

\subsubsection{STATs and Radiotherapy}

Various radiotherapeutic strategies have a differential and, sometimes, non-specific impact on the members of the STAT TF family [172]. The generalized effect of X-ray and $\gamma$-photon radiotherapy is STAT3 activation, which is observed in TAMs in response to all clinical doses of radiation. Irradiation promotes IL-6 production by the tumor microenvironment, which results in STAT3 phosphorylation and subsequent anti-inflammatory CCL2, CCL4, VEGF, and TGF- $\beta$ cytokine production $[149,158,160,189]$. It is worth noting that STAT3 signaling also promotes cell survival after irradiation exposure via induction of anti-apoptotic proteins (survivin and Bcl-2), and this effect is more profound for M2-like TAMs $[158,160,190]$. The low radiation doses show a bidirectional impact on the anti-inflammatory TFs, comprised of STAT3 stimulation, as mentioned earlier, and STAT6 suppression with high IL-5 and 13 and low TGF- $\beta$ cytokine profile $[150,156]$. Considering that NF- $\mathrm{KB}$ is also suppressed upon low-dose radiotherapy, macrophages may finally acquire anti-inflammatory characteristics, although this has to be further studied. Intermediate radiation doses stimulate the transcriptional activities of STAT1, STAT3, and STAT6 [172]. The immunomodulatory effect of such treatment is the most difficult to control, as it simultaneously triggers intracellular pro- and anti-inflammatory signaling pathways. The functional outcome likely depends on individual cell characteristics (time after infiltration of the tumor), the other TFs impacted by radiotherapy (for example, NFKB) and tumor microenvironment [191]. Finally, high-dose radiation activates STAT6 and therefore has the most pronounced anti-inflammatory effect $[149,156]$.

\subsection{Interferon Regulatory Factor (IRF)}

The IRF family is represented by nine members ranging from IRF1 to IRF9. IRFs promote host defense against viral and microbial pathogens by regulating type I and II IFN-responsive genes. IRF TFs are also active in TAMs and are linked to the pro- and antiinflammatory cytokine production [192]. IRF3, 5, 7, and 8 are involved in proinflammatory macrophage polarization and control of chemokine (S100A8, S100A9S100a9, matrix metallopeptidase (MMP) 9 and 14, CXCL2, and CCL5) production [65,75,193]. IRF3, along with IRF4, can also exhibit an alternative activity inducing the expression of anti-inflammatory genes IL1RA, IL10, IFNB [76,194].

In the context of carcinogenesis, IRFs support tumor-driven macrophage activity, particularly, promoting T-cell exhaustion, while also controlling neovascularization and proinflammatory features of TAMs [39,42,75,195-199]. It is also worth noting that IRFs are commonly involved in STAT-mediated transcription and have to be considered as a complex transcriptional network $[43,45,59,71]$.

\subsubsection{IRFs and Chemotherapy}

IRF TFs strongly echo the STAT-mediated transcription in macrophages and it becomes challenging to evaluate exclusively IRFs contribution to macrophage function. The majority of data show that chemotherapy-induced IRF activation supports the tumoricidal activity of macrophages. For instance, IRF5 activation and, subsequently, macrophage proinflammatory functionalization are induced by PARP inhibitor olaparib [145]. However, some studies show that IRFs are involved in M2-like polarization following chemotherapy and can be associated with resistance $[200,201]$. 


\subsubsection{IRFs and Radiotherapy}

The IRF input into macrophage polarization upon radiotherapy remains poorly investigated. In fact, according to the authors' knowledge, alterations in IRF1, 2, 3, and 5 activity were reported in irradiated macrophages so far $[72,73,202]$. Low dose-irradiation induces ROS generation with subsequent ATM activation to stimulate IRF5 expression and M1like macrophage polarization with increased IL-6, TNF- $\alpha$, and IFN- $\gamma$ [145]. Furthermore, IRF5 cooperates with the NF- $\mathrm{KB}$ Rel-A subunit, regulates proinflammatory cytokine gene expression, which can result in M1 polarization. However, the IRF5-NF- $\mathrm{kB}$ interactions have not yet been studied in irradiated macrophages [71]. Moderate dose-radiotherapy stimulates IRF1 and 5 revealing the potential proinflammatory effects. High radiation doses reduce IRF2 and 5 levels increasing numbers of M2-like macrophages in the tumor [151]. At least for the high-dose irradiation IRF1 is suppressed in monocytes, while upregulated in macrophages, suggesting the different responses from infiltrated cells and TAMs [72,73].

\section{4. $P 53$}

Despite the extensive studies on the tumor suppressor p53, its roles in immune cells, including TAMs, are not fully understood. It is known that p53 regulates inflammatory responses in the tumor microenvironment. In macrophages p53 is involved in cell survival and death, monocyte-to-macrophage differentiation, and M1/M2 polarization $[52,74,203,204]$. P53 is up-regulated and activated following both pro- and antiinflammatory macrophage activation and promotes pro-apoptotic pathways predominantly in M1 cells [205,206].

The majority of observations suggest that p53 is required for anti-tumor activities of TAMs, as p53 is generally associated with the proinflammatory macrophage phenotype, increased levels of IL-6 and IL-12, and enhanced phagocytic activity [52,74,203,204,207]. At the same time, p53 may restrict the performance of other M1-associated TFs STAT1, NF- $\mathrm{kB}$, IRF9, IRF5, and c-Myc [52,204,208-210]. In accordance, the p53 transcriptional activities and high levels of its target genes CDKN1A (cyclin-dependent kinase inhibitor 1), MDM2, PUMA, and BAX are detected in TAMs along with increased IL6 and CXCL1 [211]. The outcome of p53-mediated transcription in the tumor microenvironment depends on the cooperation with the other signaling molecules, such as NF-kB, STAT1, and c-Myc, p21 and some others [52,203,208-210,212-214].

\subsubsection{P53 and Chemotherapy}

P53 is involved in cell responses to cytotoxic, cytostatic, and targeted drugs, which impact macrophages. Doxorubicin, methotrexate 5-fluorouracil, and other chemotherapeutic compounds induce p53 activity in TAMs with subsequent increase in p53 target p21 and IL6 expression. The p53-driven proinflammatory polarization results in tumor sensitization to chemotherapy and is specific for monocyte/macrophage subsets [140]. Among the targeted drugs, nutlin-3, which inhibits p53/MDM2 interaction and stabilizes p53, MDM2 inhibitor APG-115, and anti-VEGF receptor 3 activate $\mathrm{p} 53$ and promote p53-NF-kB cooperation to stimulate antitumor macrophage reactivity $[52,210,211,215]$. P53 maintains the physiological levels of programmed cell death protein 1 (PD-1) ligand, restricts excessive extracellular vesicle formation, and subsequently limits T-cell exhaustion and immunosuppression. [216,217]. With that, p53 can become a multifaceted target for immunotherapy.

\subsubsection{P53 and Radiotherapy}

As a pro-apoptotic protein, p53 sensitizes cells to radiation, and this effect is also present in irradiated macrophages. P53 becomes activated in macrophages during radiotherapy and is associated with TAM polarization and modulation of cell survival. However, the impact of different irradiation doses has not been studied. At least the intermediate (4-5 Gy) irradiation increases p53 protein levels and its transcriptional activity together with the antitumor (TNF- $\alpha$, FasL) and tumorigenic activities (MMP-2, MMP9) of macrophages [218,219]. P53 is directly linked to macrophage survival, as TP53-/- 
macrophages are highly radioresistant due to reduced caspase-8 expression [220]. Interestingly, p53 proapoptotic activity is stronger in M1, than in M2, macrophages, which correlates with the improved radioresistance of M2 cells [221]. Thus, p53 may regulate the balance of pro- and anti-inflammatory macrophages in the irradiated tumor microenvironment [221,222]. P53 plays an important role in macrophages simultaneously regulating cell functional activities and survival during chemo- and radiotherapy. These facts have to be considered when applying p53-targeted therapy.

\subsection{Other Transcription Factors Affected by Radio- and Chemotherapy}

Transcriptional networks essential for macrophage polarization include a broad range of TFs, which are also involved in therapeutic responses. When summarizing the existing data it can be observed that various treatments tend to impact M2-associated TFs, such as nuclear factor erythroid 2-related factor 2 (Nrf2), peroxisome proliferator-activated receptor gamma (PPAR- $\gamma$ ), cAMP response element-binding protein (CREB), and some others, which may be due to the immunosuppressive properties of the tumor microenvironment. However, a substantial number of transcriptional mechanisms have not yet been studied in the context of chemo- and radiotherapy.

Nrf2 shifts macrophages toward anti-inflammatory polarization altering cytokine, growth factor and cell adhesion molecule profiles [223-225]. Nrf2 deficiency in myeloid cells is associated with the enhanced metastatic profile of the tumor and tumorigenic immune activity [226,227]. The Nrf2 activation orchestrated by p21, which is observed after $\gamma$-irradiation, is dose-dependent, reduces oxidative stress in macrophages, and may, thus, protect the cells against $\gamma$-ray damage [228]. While the Nrf2 activities in chemotherapy have not yet been studied, Nrf2 controls local tissue inflammation and can potentially protect TAMs from drug-induced oxidative damage [229,230].

Peroxisome proliferator-activated receptors (PPARs) comprise another family of antiinflammatory TFs [231]. Macrophage-specific PPAR- $\gamma$ impairs the chemotherapeutic efficiency [232]. During radiotherapy, PPAR $-\gamma$ is involved in macrophage activation by irradiated cancer cells and immunogenic antitumor activity thereby reducing cancer progression and metastasis [233]. Thus, regulators of PPAR- $\gamma$ may emerge as promising candidates in targeting both cancer cells and the tumor microenvironment [234].

Other candidate TFs, which can shape macrophage behavior, include cAMP response element-binding protein (CREB) and CCAAT-enhancer-binding proteins (C/EBPs) TF family [235-238]. The phosphorylated CREB inhibits NF- $\mathrm{BB}$ activation, thus limiting proinflammatory responses $[239,240]$. Furthermore, overexpression of CREB in committed macrophages provokes myeloproliferative diseases [241]. The C/EBP family consists of six members, from $\mathrm{C} / \mathrm{EBP}-\alpha$ to $\mathrm{C} / \mathrm{EBP}-\zeta$, which may function in opposite ways. For instance, $C / E B P-\alpha$ and $C / E B P-\delta$ are one of the most important TFs that contribute to the M1 polarization, whereas $C / E B P \beta$ is associated with $\mathrm{M} 2$ macrophage polarization [11,242]. Furthermore, $\mathrm{C} / \mathrm{EBP} \beta$ activated by vitamin D3 or its derivatives can aggravate alternative macrophage polarization $[225,243]$. Interestingly, $C / E B P \beta$ is downstream of the rapamycin kinase (mTOR) pathway which is a target of immunosuppressive and anticancer drugs [244,245]. Therefore, mTOR targeting drugs should be considered in the framework of macrophage polarization and could represent a novel therapeutic approach. Highmobility group box protein 1 (HMGB1) is a chromatin-binding factor that promotes M2 polarization by activation of the receptor for advanced glycation end-products (RAGE) [246]. High expression of HMGB1 in TAMs has been shown to enhance lymphatic metastasis [247]. Current observations show opposite effects after radiotherapy; HMGB1 release can lead to immunosuppression and potentiate macrophages reprogramming towards M1 phenotype [166,248]. Chemotherapy stimulates HMGB1 production to promote antigenpresenting function of immune cells [249].

Many other factors that have an impact on TAM polarization have been not yet sufficiently investigated. For example, the Maf family consists of a wide number of TFs including V-maf musculoaponeurotic fibrosarcoma oncogene homolog B (Mafb) and c-Maf. 
Both of them are highly expressed in TAMs and correlate with anti-inflammatory responses in both human and murine models [250-252]. At the same time, JunB governs functional behaviour of both pro and anti-inflammatory macrophages. JunB upregulates IL- $1 \beta$ in proinflammatory polarized macrophages while enhancing anti-inflammatory markers in M2-like cells [253]. MAP kinase-interacting kinase (Mnk2) promotes education of M2 phenotype through induction of anti-inflammatory marker translation by activation of eukaryotic translation initiation factor (eIF4E) [254]. All of them are promising research targets in the framework of resistance overcoming.

\section{Macrophage Transcription Factors in Antitumor Therapy}

Numerous preclinical and clinical studies confirm the promising effects of multitargeted combinations based on radio-, chemo-, and immunotherapy in cancer medicine $[255,256]$. The most prominent treatment effects on monocyte/macrophage subsets are associated with the increased immune cell recruitment to the tumor site and promoted antigen presentation, which are now recognized as essential components of the tumor microenvironment [257].

While numerous TAM signaling pathways become non-specifically activated by the drug or irradiation, immunotherapy can potentially direct macrophage polarization with enhanced antitumor activity [258]. In the current clinical practice the most common TAM immunotherapeutic targets are membrane receptors such as cluster of differentiation 40 (CD40) [259], SIRP- $\alpha$ [260,261], CXCR4 [262], C-C chemokine receptor 2 (CCR2), [263], CSF1R [264-266], which promote M1-like macrophage activation with enhanced antigen presentation activity and immune cell chemoattraction in lung, breast and colon cancer, Burkitt's lymphoma, and leukemia [258,267-269]. The corresponding transcriptional networks have to be additionally considered in future theranostics [270-272].

TF-based macrophage regulation can be considered as one of the most potent and efficient strategies against tumor therapeutic resistance. As described previously, a substantial number of chemical agents are already available for TAM transcriptional reprogramming. For NF- $\mathrm{KB}$-based approaches target deletion of IкB kinase $\beta$ (IKK $\beta$ ) or inhibition of downstream PI3K significantly improve antitumor activities [273,274]. TLR agonists can be used for stimulation of NF-kB-mediated transcription, as shown for alveolar macrophages and monocytes (paraquat), for lung, breast, and melanoma cancers (chloroquine), for melanoma and squamous cell carcinoma (imiquimod) [275-277]. Cancer-associated chronic inflammation may request the application of nonsteroidal-based anti-inflammatory drugs (NSAIDs), such as acetaminophen or sulindac, to suppress undesired NF- $\mathrm{kB}$-promoted production of growth and metastatic factors. Furthermore, NF- $\mathrm{kB}$ inhibition can prevent cisplatinand carboplatin-induced M2-like phenotype in cervical and ovarian cancer [85]. Other possible additives for oncotherapy may implement salicylates (aspirin, sulfasalazine, triflusal), antioxidants (pyrrolidine dithiocarbamate, $\mathrm{N}$-acetylcysteine, vitamin $\mathrm{E}$, vitamin $\mathrm{C}$ ), and peptides (SN50, nuclear localization signal peptide, NEMO-binding domain peptide, Toll/interleukin-1 receptor domain-containing adaptor protein) for non-specific NF- $\mathrm{kB}$ regulation [278-280].

STAT family-based immunotherapy can enhance the effects of $\gamma$-radiation via regulation of macrophage subset and cytokine balance in the tumor microenvironment [281]. For instance, tyrosine kinase inhibitors (sunitinib, sorafenib), WP1066, plant-derived imodin (PM37), and resveratrol inhibit STAT TF activity in macrophages and restricts M2 polarization, suggesting the improved antitumor reactivity against pancreatic adenocarcinoma, breast, and lung cancer [49,160,191,258,282-284]. Additionally, STATs, IRFs, NF-kB, and c-MYC mediated polarization can be regulated by microRNAs. MicroRNAs regulate gene expression through translation repression or mRNA degradation. It has been shown as a prospective macrophage-centered diagnostic and therapeutic strategy [22].

In conclusion, macrophage TFs are among the prospective diagnostic markers and therapeutic targets, which allow repolarize TAMs and impact tumor microenvironment preventing tumor resistance. In macrophage-based immunotherapy, various immunomodulators can be applied to optimize the chemo- or radiotherapeutic outcome and prolong 
the treatment benefits. Currently NF- $\mathrm{kB}$, STAT, and IRF transcriptional machinery, which is implied in cancer and immune cell functionality, present the most substantial potential for cancer immunotherapy. Tumor status and disease type have to be considered for preferential pro- or anti-inflammatory alterations.

Author Contributions: Conceptualization, M.S.D.; writing-original draft preparation, G.F.M. and D.O.K.; writing - review and editing, M.S.D., J.N. and A.A.S.; visualization, G.F.M., D.O.K. and J.N.; supervision, M.S.D., A.A.S. All authors have read and agreed to the published version of the manuscript.

Funding: This work was financially supported by the Government of the Russian Federation through the ITMO Fellowship and Professorship Program, and by the Russian Science Foundation (Grant No. 20-75-10112).

Conflicts of Interest: The authors declare no conflict of interest.

\section{Abbreviations}

$\begin{array}{ll}\text { ADM } & \text { Adrenomedullin } \\ \text { Arg-1 } & \text { Arginase-1 } \\ \text { ATM } & \text { Ataxia telangiectasia mutated (serine/threonine kinase) } \\ \text { BCl-xL } & \text { B-cell lymacrophageoma-extra large } \\ \text { CCL } & \text { Chemokine (C-C motif) ligand } \\ \text { CCR2 } & \text { C-C chemokine receptor 2 } \\ \text { CD40 } & \text { Cluster of differentiation 40 } \\ \text { CIITA } & \text { Class II, major histocompatibility complex, transactivator } \\ \text { COX2 } & \text { Prostaglandin-endoperoxide synthase 2 } \\ \text { CREB } & \text { cAMP response element-binding protein } \\ \text { CSF } & \text { Colony stimulating factor } \\ \text { CYP19A1 } & \text { Cytochrome P450 Family 19 Subfamily A Member 1 } \\ \text { CXCL1 } & \text { The chemokine (C-X-C motif) ligand } \\ \text { C/EBP } & \text { CCAAT/enhancer binding protein } \\ \text { DHFR } & \text { Dihydrofolate reductase } \\ \text { EGF } & \text { Epidermal growth factor } \\ \text { ERK } & \text { Mitogen-activated protein kinase } \\ \text { eIF4E } & \text { Eukaryotic translation initiation factor } \\ \text { FN1 } & \text { Fibronectin 1 } \\ \text { Fizz1 } & \text { Resistin-like beta } \\ \text { GBP6 } & \text { Guanylate binding protein } \\ \text { GM-CSF } & \text { Granulocyte-macrophage colony-stimulating factor } \\ \text { Gy } & \text { Gray } \\ \text { GDF-15 } & \text { Growth differentiation factor 15 } \\ \text { HDL } & \text { High-density lipoprotein } \\ \text { HLA } & \text { Human leukocyte antigens } \\ \text { HMGB1 } & \text { High-mobility group protein B1) } \\ \text { IFIT2 } & \text { Interferon-induced protein with tetratricopeptide repeats 2 } \\ \text { IFN } & \text { Interferon } \\ \text { IKB } & \text { Inhibitor of nuclear factor kappa B } \\ \text { IKK } & \text { IkB kinase } \\ \text { IL } & \text { Interleukin } \\ \text { iNOS } & \text { Inducible nitric oxide synthase } \\ \text { IRF } & \text { Interferon regulatory factor } \\ & \end{array}$




$\begin{array}{ll}\text { JAK } & \text { Janus kinase } \\ \text { LPS } & \text { Lipopolysaccharide } \\ \text { L-Arg } & \text { L-arginine } \\ \text { LIF } & \text { Leukemia inhibitory factor } \\ \text { MafB } & \text { V-maf musculoaponeurotic fibrosarcoma oncogene homolog B } \\ \text { MHC } & \text { Major histocompatibility complex } \\ \text { MMP } & \text { Matrix metallopeptidase } \\ \text { Mnk } & \text { MAP kinase-interacting kinase } \\ \text { MYD88 } & \text { Myeloid differentiation primary response 88 } \\ \text { NK-kB } & \text { Nuclear factor kappa-light-chain-enhancer of activated B cells } \\ \text { NRF2 } & \text { The nuclear factor erythroid 2-related factor 2 } \\ \text { NSAIDs } & \text { Nonsteroidal anti-inflammatory drugs } \\ \text { PARP } & \text { poly-ADP-ribose polymerase } \\ \text { PDTC } & \text { Pyrrolidine dithiocarbamate } \\ \text { PD-L1 } & \text { Programmed cell death 1 } \\ \text { PGE2 } & \text { Prostaglandin E2 } \\ \text { PPAR } & \text { Peroxisome proliferator-activated receptors } \\ \text { RHD } & \text { Rel homology domain } \\ \text { ROS } & \text { Reactive oxygen species } \\ \text { SDF-1 } & \text { Stromal cell-derived factor-1 } \\ \text { STAT } & \text { Signal transducer and activator of transcription } \\ \text { TAM } & \text { Tumor associated macrophage } \\ \text { TF } & \text { Transcription factor } \\ \text { TGF- } \beta & \text { Transforming growth factor beta } \\ \text { TLR } & \text { Toll-like receptor } \\ \text { TNF- } \alpha & \text { Tumor necrosis factor alpha } \\ \text { TRAF } & \text { TNF receptor associated factor } \\ \text { TRAM } & \text { TRIF-related adaptor molecule } \\ \text { HIF-1 } \alpha & \text { Hypoxia-inducible factor 1-alpha } \\ \text { VEGF } & \text { Vascular endothelial growth factor } \\ \text { Ym1 } & \text { Chitinase 3-like 3 } \\ & \end{array}$

\section{References}

1. Whiteside, T.L. The tumor microenvironment and its role in promoting tumor growth. Oncogene 2008, 27, 5904-5912. [CrossRef]

2. Balkwill, F.R.; Capasso, M.; Hagemann, T. The tumor microenvironment at a glance. J. Cell Sci. 2012, 125, 5591-5596. [CrossRef] [PubMed]

3. Macciò, A.; Gramignano, G.; Cherchi, M.C.; Tanca, L.; Melis, L.; Madeddu, C. Role of M1-polarized tumor-associated macrophages in the prognosis of advanced ovarian cancer patients. Sci. Rep. 2020, 10, 1-8. [CrossRef] [PubMed]

4. Wanderley, C.W.; Colon, D.F.; Luiz, J.P.M.; Oliveira, F.F.; Viacava, P.R.; Leite, C.A.; Pereira, J.A.; Silva, C.M.; Silva, C.R.; Silva, R.L.; et al. Paclitaxel reduces tumor growth by reprogramming tumor-associated macrophages to an M1- profile in a TLR4-dependent manner. Cancer Res. 2018, 78, 5891-5900. [CrossRef] [PubMed]

5. Garrido-Martin, E.M.; Mellows, T.W.P.; Clarke, J.; Ganesan, A.-P.; Wood, O.; Cazaly, A.; Seumois, G.; Chee, S.J.; Alzetani, A.; King, E.V.; et al. M1hot tumor-associated macrophages boost tissue-resident memory T cells infiltration and survival in human lung cancer. J. Immunother. Cancer 2020, 8, e000778. [CrossRef]

6. Petrillo, M.; Zannoni, G.F.; Martinelli, E.; Pedone Anchora, L.; Ferrandina, G.; Tropeano, G.; Fagotti, A.; Scambia, G. Polarisation of Tumor-Associated Macrophages toward M2 Phenotype Correlates with Poor Response to Chemoradia-tion and Reduced Survival in Patients with Locally Advanced Cervical Cancer. PLoS ONE 2015, 10, e0136654. [CrossRef] [PubMed]

7. Valeta-Magara, A.; Gadi, A.; Volta, V.; Walters, B.; Arju, R.; Giashuddin, S.; Zhong, H.; Schneider, R.J. Inflammatory Breast Cancer Promotes Development of M2 Tumor-Associated Macrophages and Cancer Mesenchymal Cells through a Complex Chemokine Network. Cancer Res. 2019, 79, 3360-3371. [CrossRef]

8. Xiao, M.; Zhang, J.; Chen, W.; Chen, W. M1-like tumor-associated macrophages activated by exosome-transferred THBS1 promote malignant migration in oral squamous cell carcinoma. J. Exp. Clin. Cancer Res. 2018, 37, 1-15. [CrossRef]

9. Jayasingam, S.D.; Citartan, M.; Thang, T.H.; Zin, A.A.M.; Ang, K.C.; Ch'Ng, E.S. Evaluating the Polarization of Tumor-Associated Macrophages Into M1 and M2 Phenotypes in Human Cancer Tissue: Technicalities and Challenges in Routine Clinical Practice. Front. Oncol. 2020, 9, 1512. [CrossRef]

10. Müller, E.; Christopoulos, P.F.; Halder, S.; Lunde, A.; Beraki, K.; Speth, M.; Øynebråten, I.; Corthay, A. Toll-Like Receptor Ligands and Interferon- $\gamma$ Synergize for Induction of Antitumor M1 Macrophages. Front. Immunol. 2017, 8, 1383. [CrossRef]

11. Lawrence, T.; Natoli, G. Transcriptional regulation of macrophage polarization: Enabling diversity with identity. Nat. Rev. Immunol. 2011, 11, 750-761. [CrossRef] 
12. Levy, D.E.; Kessler, D.S.; Pine, R.; Reich, N.; Darnell, J.E. Interferon-induced nuclear factors that bind a shared promoter element correlate with positive and negative transcriptional control. Genes Dev. 1988, 2, 383-393. [CrossRef] [PubMed]

13. Solinas, G.; Schiarea, S.; Liguori, M.; Fabbri, M.; Pesce, S.; Zammataro, L.; Pasqualini, F.; Nebuloni, M.; Chiabrando, C.; Mantovani, A.; et al. Tumor-Conditioned Macrophages Secrete Migration-Stimulating Factor: A New Marker for M2-Polarization, Influencing Tumor Cell Motility. J. Immunol. 2010, 185, 642-652. [CrossRef] [PubMed]

14. Chacon-Salinas, R.; Serafin-Lopez, J.; Ramos-Payan, R.; Mendez-Aragon, P.; Hernandez-Pando, R.; Van Soolingen, D.; FloresRomo, L.; Estrada-Parra, S.; Estrada-Garcia, I. Differential pattern of cytokine expression by macrophages infected in vitro with different Mycobacterium tuberculosis genotypes. Clin. Exp. Immunol. 2005, 140, 443-449. [CrossRef] [PubMed]

15. Sanford, D.E.; Belt, B.A.; Panni, R.Z.; Mayer, A.; Deshpande, A.D.; Carpenter, D.; Mitchem, J.B.; Plambeck-Suess, S.M.; Worley, L.A.; Goetz, B.D.; et al. Inflammatory Monocyte Mobilization Decreases Patient Survival in Pancreatic Cancer: A Role for Targeting the CCL2/CCR2 Axis. Clin. Cancer Res. 2013, 19, 3404-3415. [CrossRef] [PubMed]

16. Li, T.; Li, B.; Sara, A.; Ay, C.; Leung, W.Y.; Zhang, Y.; Dong, Y.; Liang, Q.; Zhang, X.; Weidner, P.; et al. Docking protein-1 promotes inflammatory macrophage signaling in gastric cancer. OncoImmunology 2019, 8, e1649961. [CrossRef]

17. Sica, A.; Larghi, P.; Mancino, A.; Rubino, L.; Porta, C.; Totaro, M.G.; Rimoldi, M.; Biswas, S.K.; Allavena, P.; Mantovani, A. Macrophage polarization in tumour progression. Semin. Cancer Biol. 2008, 18, 349-355. [CrossRef]

18. Ham, S.; Lima, L.G.; Lek, E.; Möller, A. The Impact of the Cancer Microenvironment on Macrophage Phenotypes. Front. Immunol. 2020, 11, 1308. [CrossRef]

19. Wang, Q.; He, Z.; Huang, M.; Liu, T.; Wang, Y.; Xu, H.; Duan, H.; Ma, P.; Zhang, L.; Zamvil, S.S.; et al. Vascular niche IL-6 induces alternative macrophage activation in glioblastoma through HIF-2 $\alpha$. Nat. Commun. 2018, 9, 559. [CrossRef]

20. Rőszer, T. Understanding the Mysterious M2 Macrophage through Activation Markers and Effector Mechanisms. Mediat. Inflamm. 2015, 2015, 1-16. [CrossRef]

21. Wang, Q.; Ni, H.; Lan, L.; Wei, X.; Xiang, R.; Wang, Y. Fra-1 protooncogene regulates IL-6 expression in macrophages and promotes the generation of M2d macrophages. Cell Res. 2010, 20, 701-712. [CrossRef]

22. Li, H.; Jiang, T.; Li, M.-Q.; Zheng, X.-L.; Zhao, G.-J. Transcriptional Regulation of Macrophages Polarization by MicroRNAs. Front. Immunol. 2018, 9, 1175. [CrossRef] [PubMed]

23. Platanitis, E.; Decker, T. Regulatory Networks Involving STATs, IRFs, and NFkB in Inflammation. Front. Immunol. 2018, 9, 2542. [CrossRef]

24. Rius, J.; Guma, M.; Schachtrup, C.; Akassoglou, K.; Zinkernagel, A.S.; Nizet, V.; Johnson, R.S.; Haddad, G.G.; Karin, M. NF-кB links innate immunity to the hypoxic response through transcriptional regulation of HIF-1 $\alpha$. Nat. Cell Biol. 2008, 453, 807-811. [CrossRef] [PubMed]

25. Frede, S.; Stockmann, C.; Freitag, P.; Fandrey, J. Bacterial lipopolysaccharide induces HIF-1 activation in human monocytes via p44/42 MAPK and NF-kB. Biochem. J. 2006, 396, 517-527. [CrossRef]

26. Hwang, D.; Jang, B.C.; Yu, G.; Boudreau, M. Expression of mitogen-inducible cyclooxygenase induced by lipopolysaccharide. Biochem. Pharmacol. 1997, 54, 87-96. [CrossRef]

27. Kim, J.-B.; Han, A.-R.; Park, E.-Y.; Kim, J.-Y.; Cho, W.; Lee, J.; Seo, E.-K.; Lee, K.-T. Inhibition of LPS-Induced iNOS, COX-2 and Cytokines Expression by Poncirin through the NF-.KAPPA.B Inactivation in RAW 264.7 Macrophage Cells. Biol. Pharm. Bull. 2007, 30, 2345-2351. [CrossRef]

28. Liu, C.-P.; Zhang, X.; Tan, Q.-L.; Xu, W.-X.; Zhou, C.-Y.; Luo, M.; Li, X.; Huang, R.-Y.; Zeng, X. NF-kB pathways are involved in M1 polarization of RAW 264.7 macrophage by polyporus polysaccharide in the tumor microenvironment. PLoS ONE 2017, 12, e0188317. [CrossRef]

29. Shan, S.; Fang, B.; Zhang, Y.; Wang, C.; Zhou, J.; Niu, C.; Gao, Y.; Zhao, D.; He, J.; Wang, J.; et al. Mechanical stretch promotes tumoricidal M1 polarization via the FAK/NF-kB signaling pathway. FASEB J. 2019, 33, 13254-13266. [CrossRef] [PubMed]

30. Wager, C.M.L.; Hole, C.R.; Campuzano, A.; Castro-Lopez, N.; Cai, H.; Van Dyke, M.C.C.; Wozniak, K.L.; Wang, Y.; Wormley, F.L., Jr. IFN- $\gamma$ immune priming of macrophages in vivo induces prolonged STAT1 binding and protection against Cryptococcus neoformans. PLoS Pathog. 2018, 14, e1007358. [CrossRef]

31. Darnell, J.E.; Kerr, I.M.; Stark, G.R. Jak-STAT pathways and transcriptional activation in response to IFNs and other extracellular signaling proteins. Science 1994, 264, 1415-1421. [CrossRef] [PubMed]

32. Van Der Vorst, E.P.; Theodorou, K.; Wu, Y.; Hoeksema, M.A.; Goossens, P.; Bursill, C.A.; Aliyev, T.; Huitema, L.F.; Tas, S.W.; Wolfs, I.M.; et al. High-Density Lipoproteins Exert Pro-inflammatory Effects on Macrophages via Passive Cholesterol Depletion and PKC-NF-кB/STAT1-IRF1 Signaling. Cell Metab. 2017, 25, 197-207. [CrossRef] [PubMed]

33. Liu, X.; Yin, S.; Chen, Y.; Wu, Y.; Zheng, W.; Dong, H.; Bai, Y.; Qin, Y.; Li, J.; Feng, S.; et al. LPS-induced proinflammatory cytokine expression in human airway epithelial cells and macrophages via NF-кB, STAT3 or AP-1 activation. Mol. Med. Rep. 2018, 17, 5484-5491. [CrossRef] [PubMed]

34. Ribechini, E.; Hutchinson, J.A.; Hergovits, S.; Heuer, M.; Lucas, J.; Schleicher, U.; Garrote, A.-L.J.; Potter, S.J.; Riquelme, P.; Brackmann, H.; et al. Novel GM-CSF signals via IFN- $\gamma$ R/IRF-1 and AKT/mTOR license monocytes for suppressor function. Blood Adv. 2017, 1, 947-960. [CrossRef]

35. Xie, C.; Liu, C.; Wu, B.; Lin, Y.; Ma, T.; Xiong, H.; Wang, Q.; Changli, X.; Ma, C.; Tu, Z. Effects of IRF1 and IFN- $\beta$ interaction on the M1 polarization of macrophages and its antitumor function. Int. J. Mol. Med. 2016, 38, 148-160. [CrossRef] [PubMed] 
36. Lehtonen, A.; Matikainen, S.; Julkunen, I. Interferons up-regulate STAT1, STAT2, and IRF family transcription factor gene expression in human peripheral blood mononuclear cells and macrophages. J. Immunol. 1997, 159, 794.

37. Cuesta, N.; Salkowski, C.A.; Thomas, K.E.; Vogel, S.N. Regulation of Lipopolysaccharide Sensitivity by IFN Regulatory Factor-2. J. Immunol. 2003, 170, 5739-5747. [CrossRef]

38. Han, H.-S.; Shin, J.-S.; Lee, S.-B.; Park, J.C.; Lee, K.-T. Cirsimarin, a flavone glucoside from the aerial part of Cirsium japonicum var. ussuriense (Regel) Kitam. ex Ohwi, suppresses the JAK/STAT and IRF-3 signaling pathway in LPS-stimulated RAW 264.7 macrophages. Chem. Interact. 2018, 293, 38-47. [CrossRef]

39. Krausgruber, T.; Blazek, K.; Smallie, T.; Alzabin, S.; Lockstone, H.; Sahgal, N.; Hussell, T.; Feldmann, M.; Udalova, I.A. IRF5 promotes inflammatory macrophage polarization and TH1-TH17 responses. Nat. Immunol. 2011, 12, 231-238. [CrossRef]

40. Li, C.; Ying, W.; Huang, Z.; Brehm, T.; Morin, A.; Vella, A.T.; Zhou, B. IRF6 Regulates Alternative Activation by Suppressing PPAR $\gamma$ in Male Murine Macrophages. Endocrinology 2017, 158, 2837-2847. [CrossRef] [PubMed]

41. Solis, M.; Goubau, D.; Grandvaux, N.; Mesplede, T.; Julkunen, I.; Nardin, A.; Salcedo, M.; Hiscott, J.; Romieu-Mourez, R. Involvement of TBK1 and IKK $\varepsilon$ in lipopolysaccharide-induced activation of the interferon response in primary human macrophages. Eur. J. Immunol. 2007, 37, 528-539. [CrossRef] [PubMed]

42. Pinilla-Vera, M.; Xiong, Z.; Zhao, Y.; Zhao, J.; Donahoe, M.P.; Barge, S.; Horne, W.T.; Kolls, J.K.; McVerry, B.J.; Birukova, A.; et al. Full Spectrum of LPS Activation in Alveolar Macrophages of Healthy Volunteers by Whole Transcriptomic Profiling. PLoS ONE 2016, 11, e0159329. [CrossRef]

43. Sol, V.V.-D.; Punzón, C.; Fresno, M. IFN- $\gamma$-Induced TNF- $\alpha$ Expression Is Regulated by Interferon Regulatory Factors 1 and 8 in Mouse Macrophages. J. Immunol. 2008, 181, 4461-4470. [CrossRef]

44. Shen, J.; Sun, X.; Pan, B.; Cao, S.; Cao, J.; Che, D.; Liu, F.; Zhang, S.; Yu, Y. IL-17 induces macrophages to M2-like phenotype via NF-кB. Cancer Manag. Res. 2018, 10, 4217-4228. [CrossRef] [PubMed]

45. Sica, A.; Saccani, A.; Bottazzi, B.; Polentarutti, N.; Vecchi, A.; Van Damme, J.; Mantovani, A. Autocrine Production of IL-10 Mediates Defective IL-12 Production and NF-кB Activation in Tumor-Associated Macrophages. J. Immunol. 2000, 164, 762-767. [CrossRef] [PubMed]

46. Ratnam, N.M.; Peterson, J.M.; Talbert, E.E.; Ladner, K.J.; Rajasekera, P.V.; Schmidt, C.R.; Dillhoff, M.E.; Swanson, B.J.; Haverick, E.; Kladney, R.D.; et al. NF-kB regulates GDF-15 to suppress macrophage surveillance during early tumor development. J. Clin. Investig. 2017, 127, 3796-3809. [CrossRef]

47. Giurisato, E.; Xu, Q.; Lonardi, S.; Telfer, B.; Russo, I.; Pearson, A.; Finegan, K.G.; Wang, W.; Wang, J.; Gray, N.S.; et al. Myeloid ERK5 deficiency suppresses tumor growth by blocking protumor macrophage polarization via STAT3 inhibition. Proc. Natl. Acad. Sci. USA 2018, 115, E2801-E2810. [CrossRef]

48. Yin, Z.; Ma, T.; Lin, Y.; Lu, X.; Zhang, C.; Chen, S.; Jian, Z. IL-6/STAT3 pathway intermediates M1/M2 macrophage polarization during the development of hepatocellular carcinoma. J. Cell. Biochem. 2018, 119, 9419-9432. [CrossRef] [PubMed]

49. Rahal, O.M.; Wolfe, A.R.; Mandal, P.K.; Larson, R.; Tin, S.; Jimenez, C.; Zhang, D.; Horton, J.; Reuben, J.M.; McMurray, J.S.; et al. Blocking Interleukin (IL)4- and IL13-Mediated Phosphorylation of STAT6 (Tyr641) Decreases M2 Polarization of Macrophages and Protects Against Macrophage-Mediated Radioresistance of Inflammatory Breast Cancer. Int. J. Radiat. Oncol. 2018, 100, 1034-1043. [CrossRef] [PubMed]

50. Brady, N.J.; Farrar, M.A.; Schwertfeger, K.L. STAT5 deletion in macrophages alters ductal elongation and branching during mammary gland development. Dev. Biol. 2017, 428, 232-244. [CrossRef]

51. Honma, K.; Udono, H.; Kohno, T.; Yamamoto, K.; Ogawa, A.; Takemori, T.; Kumatori, A.; Suzuki, S.; Matsuyama, T.; Yui, K. Interferon regulatory factor 4 negatively regulates the production of proinflammatory cytokines by macrophages in response to LPS. Proc. Natl. Acad. Sci. USA 2005, 102, 16001-16006. [CrossRef] [PubMed]

52. Li, L.; Ng, D.S.W.; Mah, W.-C.; Almeida, F.F.; Rahmat, S.A.; Rao, V.K.; Leow, S.C.; Laudisi, F.; Peh, M.T.; Goh, A.M.; et al. A unique role for p53 in the regulation of M2 macrophage polarization. Cell Death Differ. 2014, 22, 1081-1093. [CrossRef] [PubMed]

53. Zhou, W.; Zhang, Y.; He, F.; Lv, S.; Zhang, X.; Fei, C. Abundance of CD163-Positive Tumor-Associated Macrophages in the Early Gastric Cancer Predicts the Recurrence after Curative Resection. Dig. Dis. 2020, 38, 458-465. [CrossRef]

54. Curtis, L.T.; Leonard, F.; Godin, B.; Friebos, H.B. Modeling of the tumor microenvironment to highlight nonlinear interactions between chemotherapeutic response and macrophage polarization state. J. Clin. Oncol. 2018, 36, e24120. [CrossRef]

55. Cao, L.; Che, X.; Qiu, X.; Li, Z.; Yang, B.; Wang, S.; Hou, K.; Fan, Y.; Qu, X.; Liu, Y. M2 macrophage infiltration into tumor islets leads to poor prognosis in non-small-cell lung cancer. Cancer Manag. Res. 2019, 11, 6125-6138. [CrossRef] [PubMed]

56. Salmi, S.; Siiskonen, H.; Sironen, R.; Tyynelä-Korhonen, K.; Hirschovits-Gerz, B.; Valkonen, M.; Auvinen, P.; Pasonen-Seppänen, S. The number and localization of CD68+ and CD163+ macrophages in different stages of cutaneous melanoma. Melanoma Res. 2019, 29, 237-247. [CrossRef] [PubMed]

57. Yang, C.; Wei, C.; Wang, S.; Shi, D.; Zhang, C.; Lin, X.; Dou, R.; Xiong, B. Elevated CD163+/CD68+ Ratio at Tumor Invasive Front is Closely Associated with Aggressive Phenotype and Poor Prognosis in Colorectal Cancer. Int. J. Biol. Sci. 2019, 15, 984-998. [CrossRef] [PubMed]

58. Lanciotti, M.; Masieri, L.; Raspollini, M.R.; Minervini, A.; Mari, A.; Comito, G.; Giannoni, E.; Carini, M.; Chiarugi, P.; Serni, S. The Role of M1 and M2 Macrophages in Prostate Cancer in relation to Extracapsular Tumor Extension and Biochemical Recurrence after Radical Prostatectomy. BioMed Res. Int. 2014, 2014, 1-6. [CrossRef] 
59. Yuan, X.; Zhang, J.; Li, D.; Mao, Y.; Mo, F.; Du, W.; Ma, X. Prognostic significance of tumor-associated macrophages in ovarian cancer: A meta-analysis. Gynecol. Oncol. 2017, 147, 181-187. [CrossRef]

60. McMillan, D.C.; Elahi, M.M.; Sattar, N.; Angerson, W.J.; Johnstone, J.; McArdle, C.S. Measurement of the Systemic Inflammatory Response Predicts Cancer-Specific and Non-Cancer Survival in Patients with Cancer. Nutr. Cancer 2001, 41, 64-69. [CrossRef]

61. Biswas, S.K.; Mantovani, A. Macrophage plasticity and interaction with lymphocyte subsets: Cancer as a paradigm. Nat. Immunol. 2010, 11, 889-896. [CrossRef]

62. Lewis, C.E.; Pollard, J.W. Distinct Role of Macrophages in Different Tumor Microenvironments. Cancer Res. 2006, 66, 605-612. [CrossRef] [PubMed]

63. Bottazzi, B.; Walter, S.; Govoni, D.; Colotta, F.; Mantovani, A. Monocyte chemotactic cytokine gene transfer modulates macrophage infiltration, growth, and susceptibility to IL-2 therapy of a murine melanoma. J. Immunol. 1992, 148, 1280-1285. [CrossRef]

64. Mantovani, A.; Sozzani, S.; Locati, M.; Allavena, P.; Sica, A. Macrophage polarization: Tumor-associated macrophages as a paradigm for polarized M2 mononuclear phagocytes. Trends Immunol. 2002, 23, 549-555. [CrossRef]

65. Wang, N.; Liang, H.; Zen, K. Molecular Mechanisms That Influence the Macrophage M1â€“M2 Polarization Balance. Front. Immunol. 2014, 5, 614. [CrossRef] [PubMed]

66. Richmond, A. NF- $\mathrm{B}$, chemokine gene transcription and tumour growth. Nat. Rev. Immunol. 2002, 2, 664-674. [CrossRef] [PubMed]

67. Mancino, A.; Lawrence, T. Nuclear Factor- B and Tumor-Associated Macrophages. Clin. Cancer Res. 2010, 16, 784-789. [CrossRef]

68. Genard, G.; Wera, A.-C.; Huart, C.; Le Calve, B.; Penninckx, S.; Fattaccioli, A.; Tabarrant, T.; Demazy, C.; Ninane, N.; Heuskin, A.-C.; et al. Proton irradiation orchestrates macrophage reprogramming through NFkB signaling. Cell Death Dis. 2018, 9, 1-13. [CrossRef]

69. Lin, E.Y.; Li, J.-F.; Gnatovskiy, L.; Deng, Y.; Zhu, L.; Grzesik, D.A.; Qian, H.; Xue, X.-N.; Pollard, J.W. Macrophages Regulate the Angiogenic Switch in a Mouse Model of Breast Cancer. Cancer Res. 2006, 66, 11238-11246. [CrossRef]

70. Lawrence, T. Macrophages and NF-kB in Cancer. Curr. Top. Microbiol. Immunol. 2010, 349, 171-184. [CrossRef]

71. Muñoz-Fontela, C.; Mandinova, A.; Aaronson, S.A.; Lee, A.M.S.W. Emerging roles of p53 and other tumour-suppressor genes in immune regulation. Nat. Rev. Immunol. 2016, 16, 741-750. [CrossRef] [PubMed]

72. Purbey, P.K.; Scumpia, P.O.; Kim, P.J.; Tong, A.-J.; Iwamoto, K.S.; McBride, W.H.; Smale, S.T. Defined Sensing Mechanisms and Signaling Pathways Contribute to the Global Inflammatory Gene Expression Output Elicited by Ionizing Radiation. Immunology 2017, 47, 421-434.e3. [CrossRef]

73. Wang, P.; Guo, F.; Han, L.; Wang, X.; Li, J.; Guo, Y.; Lu, Y. X-ray-Induced Changes in the Expression of Inflammation-Related Genes in Human Peripheral Blood. Int. J. Mol. Sci. 2014, 15, 19516-19534. [CrossRef] [PubMed]

74. Essandoh, K.; Li, Y.; Huo, J.; Fan, G.-C. MiRNA-Mediated Macrophage Polarization and its Potential Role in the Regulation of Inflammatory Response. Shock. 2016, 46, 122-131. [CrossRef]

75. Romieu-Mourez, R.; Solis, M.; Nardin, A.; Goubau, D.; Baron-Bodo, V.; Lin, R.; Massie, B.; Salcedo, M.; Hiscott, J. Distinct Roles for IFN Regulatory Factor (IRF)-3 and IRF-7 in the Activation of Antitumor Properties of Human Macrophages. Cancer Res. 2006, 66, 10576-10585. [CrossRef]

76. Chistiakov, D.A.; Myasoedova, V.A.; Revin, V.V.; Orekhov, A.N.; Bobryshev, Y.V. The impact of interferon-regulatory factors to macrophage differentiation and polarization into M1 and M2. Immunobiology 2018, 223, 101-111. [CrossRef] [PubMed]

77. Zhang, Z.; Sun, C.; Li, C.; Jiao, X.; Griffin, B.B.; Dongol, S.; Wu, H.; Zhang, C.; Cao, W.; Dong, R.; et al. Upregulated MELK Leads to Doxorubicin Chemoresistance and M2 Macrophage Polarization via the miR-34a/JAK2/STAT3 Pathway in Uterine Leiomyosarcoma. Front. Oncol. 2020, 10, 453. [CrossRef] [PubMed]

78. Sica, A.; Mantovani, A. Macrophage plasticity and polarization: In vivo veritas. J. Clin. Investig. 2012, 122, 787-795. [CrossRef]

79. Takaishi, K.; Komohara, Y.; Tashiro, H.; Ohtake, H.; Nakagawa, T.; Katabuchi, H.; Takeya, M. Involvement of M2-polarized macrophages in the ascites from advanced epithelial ovarian carcinoma in tumor progression via Stat3 activation. Cancer Sci. 2010, 101, 2128-2136. [CrossRef]

80. Vasquez-Dunddel, D.; Pan, F.; Zeng, Q.; Gorbounov, M.; Albesiano, E.; Fu, J.; Blosser, R.L.; Tam, A.J.; Bruno, T.; Zhang, H.; et al. STAT3 regulates arginase-I in myeloid-derived suppressor cells from cancer patients. J. Clin. Investig. 2013, 123, 1580-1589. [CrossRef]

81. Buhtoiarov, I.N.; Sondel, P.M.; Wigginton, J.M.; Buhtoiarova, T.N.; Yanke, E.M.; Mahvi, D.A.; Rakhmilevich, A.L. Anti-tumour synergy of cytotoxic chemotherapy and anti-CD40 plus CpG-ODN immunotherapy through repolarization of tumour-associated macrophages. Immunology 2010, 132, 226-239. [CrossRef]

82. Javeed, A.; Ashraf, M.; Riaz, A.; Ghafoor, A.; Afzal, S.; Mukhtar, M.M. Paclitaxel and immune system. Eur. J. Pharm. Sci. 2009, 38, 283-290. [CrossRef] [PubMed]

83. Bryniarski, K.; Szczepanik, M.; Ptak, M.; Zemelka, M.; Ptak, W. Influence of cyclophosphamide and its metabolic products on the activity of peritoneal macrophages in mice. Pharmacol. Rep. 2009, 61, 550-557. [CrossRef]

84. Chauhan, P.; Sodhi, A.; Shrivastava, A. Cisplatin primes murine peritoneal macrophages for enhanced expression of nitric oxide, proinflammatory cytokines, TLRs, transcription factors and activation of MAP kinases upon co-incubation with L929 cells. Immunobiology 2009, 214, 197-209. [CrossRef] [PubMed] 
85. Dijkgraaf, E.M.; Heusinkveld, M.; Tummers, B.; Vogelpoel, L.T.C.; Goedemans, R.; Jha, V.; Nortier, J.W.R.; Welters, M.J.P.; Kroep, J.R.; Van Der Burg, S.H. Chemotherapy Alters Monocyte Differentiation to Favor Generation of Cancer-Supporting M2 Macrophages in the Tumor Microenvironment. Cancer Res. 2013, 73, 2480-2492. [CrossRef] [PubMed]

86. Jinushi, M.; Chiba, S.; Yoshiyama, H.; Masutomi, K.; Kinoshita, I.; Dosaka-Akita, H.; Yagita, H.; Takaoka, A.; Tahara, H. Tumorassociated macrophages regulate tumorigenicity and anticancer drug responses of cancer stem/initiating cells. Proc. Natl. Acad. Sci. USA 2011, 108, 12425-12430. [CrossRef] [PubMed]

87. Laoui, D.; Van Overmeire, E.; Van Ginderachter, J.A. Unsuspected allies: Chemotherapy teams up with immunity to fight cancer. Eur. J. Immunol. 2013, 43, 2538-2542. [CrossRef]

88. Stakheyeva, M.; Riabov, V.; Mitrofanova, I.; Litviakov, N.; Choynzonov, E.; Cherdyntseva, N.; Kzhyshkowska, J. Role of the Immune Component of Tumor Microenvironment in the Efficiency of Cancer Treatment: Perspectives for the Personalized Therapy. Curr. Pharm. Des. 2017, 23, 4807-4826. [CrossRef]

89. Weizman, N.; Krelin, Y.; Shabtayorbach, A.; Amit, M.; Binenbaum, Y.; Wong, R.J.; Gil, Z. Macrophages mediate gemcitabine resistance of pancreatic adenocarcinoma by upregulating cytidine deaminase. Oncogene 2013, 33, 3812-3819. [CrossRef]

90. Yin, Y.; Yao, S.; Hu, Y.; Feng, Y.; Li, M.; Bian, Z.; Zhang, J.; Qin, Y.; Qi, X.; Zhou, L.; et al. The Immune-microenvironment Confers Chemoresistance of Colorectal Cancer through Macrophage-Derived IL6. Clin. Cancer Res. 2017, 23, 7375-7387. [CrossRef]

91. Mitchem, J.B.; Brennan, D.J.; Knolhoff, B.L.; Belt, B.A.; Zhu, Y.; Sanford, D.E.; Belaygorod, L.; Carpenter, D.; Collins, L.; PiwnicaWorms, D.; et al. Targeting tumor-infiltrating macrophages decreases tumor-initiating cells, relieves immunosuppression, and improves chemotherapeutic responses. Cancer Res. 2013, 73, 1128-1141. [CrossRef] [PubMed]

92. Hughes, R.; Qian, B.-Z.; Rowan, C.; Muthana, M.; Keklikoglou, I.; Olson, O.C.; Tazzyman, S.; Danson, S.; Addison, C.L.; Clemons, M.; et al. Perivascular M2 Macrophages Stimulate Tumor Relapse after Chemotherapy. Cancer Res. 2015, 75, 3479-3491. [CrossRef]

93. Anttila, J.V.; Shubin, M.; Cairns, J.; Borse, F.; Guo, Q.; Mononen, T.; Vázquez-García, I.; Pulkkinen, O.; Mustonen, V. Contrasting the impact of cytotoxic and cytostatic drug therapies on tumour progression. PLoS Comput. Biol. 2019, 15, e1007493. [CrossRef] [PubMed]

94. Lao, J.; Madani, J.; Puértolas, T.; Lvarez, M.; Hernández, A.; Pazo-Cid, R.; Artal, Á.; Torres, A.A. Liposomal Doxorubicin in the Treatment of Breast Cancer Patients: A Review. J. Drug Deliv. 2013, 2013, 1-12. [CrossRef] [PubMed]

95. Al-Gallab, M.I.; Naddaf, L.A.; Kanan, M.R. The management of non-invasive bladder tumours with Doxorubicin in-travesical instillation after transurethral resection. Sultan Qaboos Univ. Med. J. 2009, 9, 53-58. [PubMed]

96. James, N.; Coker, R.; Tomlinson, D.; Harris, J.; Gompels, M.; Pinching, A.; Stewart, J. Liposomal doxorubicin (Doxil): An effective new treatment for Kaposi's sarcoma in AIDS. Clin. Oncol. 1994, 6, 294-296. [CrossRef]

97. Lori, J.C.; Stein, T.J.; Thamm, D.H. Doxorubicin and cyclophosphamide for the treatment of canine lymphoma: A randomized, placebo-controlled study*. Veter. Comp. Oncol. 2010, 8, 188-195. [CrossRef]

98. Lister, T.A.; Whitehouse, J.M.; Beard, M.E.; Brearley, R.L.; Wrigley, P.F.; Oliver, R.T.; Freeman, J.E.; Woodruff, R.K.; Malpas, J.S.; Paxton, A.M.; et al. Combination chemotherapy for acute lymphoblastic leukaemia in adults. BMJ 1978, 1, 199-203. [CrossRef]

99. Thorn, C.F.; Oshiro, C.; Marsh, S.; Hernandez-Boussard, T.; McLeod, H.; Klein, T.E.; Altman, R.B. Doxorubicin pathways. Pharm. Genom. 2011, 21, 440-446. [CrossRef]

100. Baghdadi, M.; Wada, H.; Nakanishi, S.; Abe, H.; Han, N.; Putra, W.E.; Endo, D.; Watari, H.; Sakuragi, N.; Hida, Y.; et al. Chemotherapy-Induced IL34 Enhances Immunosuppression by Tumor-Associated Macrophages and Mediates Survival of Chemoresistant Lung Cancer Cells. Cancer Res. 2016, 76, 6030-6042. [CrossRef]

101. Hortobagyi, G.N.; Holmes, F.A.; Theriault, R.L.; Buzdar, A.U. Use of Taxol (Paclitaxel) in Breast Cancer. Oncology 1994, 51, $29-32$. [CrossRef] [PubMed]

102. Johnson, D.H.; Chang, A.Y.; Ettinger, D.S. Taxol (paclitaxel) in the treatment of lung cancer: The Eastern Cooperative Oncology Group experience. Ann. Oncol. 1994, 5 (Suppl. S6), S45-S50.

103. Ercolak, V.; Sahin, B.; Gunaldi, M.; Duman, B.B.; Afsar, C.U. Efficacy of paclitaxel in the treatment of Kaposi sarcoma. Eur. Rev. Med. Pharmacol. Sci. 2015, 19, 4095-4100. [PubMed]

104. Machida, H.; Moeini, A.; Ciccone, M.A.; Mostofizadeh, S.; Takiuchi, T.; Brunette, L.L.; Roman, L.D.; Matsuo, K. Efficacy of Modified Dose-dense Paclitaxel in Recurrent Cervical Cancer. Am. J. Clin. Oncol. 2018, 41, 851-860. [CrossRef] [PubMed]

105. Ma, W.W.; Hidalgo, M. The Winning Formulation: The Development of Paclitaxel in Pancreatic Cancer. Clin. Cancer Res. 2013, 19, 5572-5579. [CrossRef] [PubMed]

106. Horwitz, S.B. Taxol (paclitaxel): Mechanisms of action. Ann. Oncol. 1994, 5, 3-6.

107. Yule, S.M.; Price, L.; McMahon, A.D.; Pearson, A.D.J.; Boddy, A.V. Cyclophosphamide Metabolism in Children with NonHodgkin's Lymphoma. Clin. Cancer Res. 2004, 10, 455-460. [CrossRef]

108. Fairley, G.H.; Patterson, M.J.L.; Scott, R.B. Chemotherapy of Hodgkin's Disease with Cyclophosphamide, Vinblastine, and Procarbazine. BMJ 1966, 2, 75-78. [CrossRef]

109. Scarisbrick, J.; Child, F.; Clift, A.; Sabroe, R.; Whittaker, S.; Spittle, M.; Russell-Jones, R. A trial of fludarabine and cyclophosphamide combination chemotherapy in the treatment of advanced refractory primary cutaneous T-cell lymphoma. Br. J. Dermatol. 2001, 144, 1010-1015. [CrossRef]

110. Ito, S.; Oyake, T.; Murai, K.; Ishida, Y. Successful Use of Cyclophosphamide as an Add-On Therapy for Multiple Myeloma Patients with Acquired Resistance to Bortezomib or Lenalidomide. Case Rep. Hematol. 2013, 2013, 1-5. [CrossRef] 
111. Zhao, Y.-R.; Song, H.-M.; Ni, L. Cyclophosphamide for the treatment of acute lymphoblastic leukemia. Medicine 2019,98 , e14293. [CrossRef]

112. Mustafa, M.M.; Jamshed, A.; Khafaga, Y.; Mourad, W.A.; Al-Mesfer, S.; Kofide, A.; El-Husseiny, G.; Gray, A. Adjuvant Chemotherapy with Vincristine, Doxorubicin, and Cyclophosphamide in the Treatment of Postenucleation High Risk Retinoblastoma. J. Pediatr. Hematol. 1999, 21, 364-369. [CrossRef]

113. Ashraf, K.; Shaikh, F.; Gibson, P.; Baruchel, S.; Irwin, M.S. Treatment with topotecan plus cyclophosphamide in children with first relapse of neuroblastoma. Pediatr. Blood Cancer 2013, 60, 1636-1641. [CrossRef]

114. Handolias, D.; Quinn, M.; Foo, S.; Mileshkin, L.; Grant, P.; Dutu, G.; Rischin, D. Oral cyclophosphamide in recurrent ovarian cancer. Asia Pac. J. Clin. Oncol. 2013, 12, e154-e160. [CrossRef]

115. Mills, K.A.; Chess-Williams, R.; McDermott, C. Novel insights into the mechanism of cyclophosphamide-induced bladder toxicity: chloroacetaldehyde's contribution to urothelial dysfunction in vitro. Arch. Toxicol. 2019, 93, 3291-3303. [CrossRef]

116. Ahlmann, M.; Hempel, G. The effect of cyclophosphamide on the immune system: Implications for clinical cancer therapy. Cancer Chemother. Pharmacol. 2016, 78, 661-671. [CrossRef]

117. Aldossary, S.A. Review on Pharmacology of Cisplatin: Clinical Use, Toxicity and Mechanism of Resistance of Cisplatin. Biomed. Pharmacol. J. 2019, 12, 7-15. [CrossRef]

118. Serkies, K.; Jassem, J. Concurrent weekly cisplatin and radiotherapy in routine management of cervical cancer: A report on patient compliance and acute toxicity. Int. J. Radiat. Oncol. 2004, 60, 814-821. [CrossRef] [PubMed]

119. Ilson, D.H. Esophageal Cancer Chemotherapy: Recent Advances. Gastrointest Cancer Res. 2008, 2, 85-92.

120. Sledge, G.W.; Roth, B.J. Cisplatin in the management of breast cancer. Semin. Oncol. 1989, 16, 110-115. [PubMed]

121. Rodrigo, M.A.M.; Buchtelova, H.; Jimenez, A.M.J.; Adam, P.; Babula, P.; Heger, Z.; Adam, V. Transcriptomic Landscape of Cisplatin-Resistant Neuroblastoma Cells. Cells 2019, 8, 235. [CrossRef]

122. Shani, J.; Wolf, W. Modalities of Cisplatin Administration to Brain Tumors. Cancer Investig. 1989, 7, 571-579. [CrossRef] [PubMed]

123. Siddik, Z.H. Cisplatin: Mode of cytotoxic action and molecular basis of resistance. Oncogene 2003, 22, 7265-7279. [CrossRef] [PubMed]

124. Chauhan, P.; Sodhi, A.; Tarang, S. Cisplatin-treated murine peritoneal macrophages induce apoptosis in L929 cells: Role of Fas-Fas ligand and tumor necrosis factor-tumor necrosis factor receptor 1. Anti Cancer Drugs 2007, 18, 187-196. [CrossRef] [PubMed]

125. Di Caro, G.; Cortese, N.; Castino, G.F.; Grizzi, F.; Gavazzi, F.; Ridolfi, C.; Capretti, G.; Mineri, R.; Todoric, J.; Zerbi, A.; et al. Dual prognostic significance of tumour-associated macrophages in human pancreatic adenocarcinoma treated or untreated with chemotherapy. Gut 2016, 65, 1710-1720. [CrossRef] [PubMed]

126. Ozols, R.F.; Bundy, B.N.; Greer, B.E.; Fowler, J.M.; Clarke-Pearson, D.; Burger, R.A.; Mannel, R.S.; DeGeest, K.; Hartenbach, E.M.; Baergen, R. Phase III Trial of Carboplatin and Paclitaxel Compared with Cisplatin and Paclitaxel in Patients With Optimally Resected Stage III Ovarian Cancer: A Gynecologic Oncology Group Study. J. Clin. Oncol. 2003, 21, 3194-3200. [CrossRef] [PubMed]

127. Ettinger, D.S. The role of carboplatin in the treatment of small-cell lung cancer. Oncology 1998, 12, 36-43.

128. Aisner, J.; Sinibaldi, V.; Eisenberger, M. Carboplatin in the treatment of squamous cell head and neck cancers. Semin. Oncol. 1992, 19, 60-65.

129. Xia, Y.; Li, Y.-H.; Chen, Y.; Liu, Q.; Zhang, J.-H.; Deng, J.-Y.; Ai, T.-S.; Zhu, H.-T.; Badakhshi, H.; Zhao, K.-L. A phase II trial of concurrent chemoradiotherapy with weekly paclitaxel and carboplatin in advanced oesophageal carcinoma. Int. J. Clin. Oncol. 2018, 23, 458-465. [CrossRef] [PubMed]

130. Michener, C.M.; Peterson, G.; Kulp, B.; Webster, K.D.; Markman, M. Carboplatin plus paclitaxel in the treatment of advanced or recurrent endometrial carcinoma. J. Cancer Res. Clin. Oncol. 2005, 131, 581-584. [CrossRef] [PubMed]

131. Valsecchi, M.E.; Kimmey, G.; Bir, A.; Silbermins, D. Role of Carboplatin in the Treatment of Triple Negative Early- Stage Breast Cancer. Rev. Recent Clin. Trials 2015, 10, 101-110. [CrossRef] [PubMed]

132. Sebastião, A.M.; Rocha, L.S.D.S.; Gimenez, R.D.; De Barros, L.A.B.; Fukushima, J.T.; Da Silva, S.C.S.; Miranda, V.D.C.; Caires, I.Q.D.S.; De Freitas, D.; Filho, E.A.; et al. Carboplatin-based chemoradiotherapy in advanced cervical cancer: An alternative to cisplatin-based regimen? Eur. J. Obstet. Gynecol. Reprod. Biol. 2016, 201, 161-165. [CrossRef]

133. Hah, S.S.; Stivers, K.M.; White, R.W.D.V.; Henderson, P.T. Kinetics of Carboplatin-DNA Binding in Genomic DNA and Bladder Cancer Cells As Determined by Accelerator Mass Spectrometry. Chem. Res. Toxicol. 2006, 19, 622-626. [CrossRef] [PubMed]

134. Vogl, S.E.; Moukhtar, M.; Kaplan, B.H. Chemotherapy for advanced cervical cancer with methotrexate, bleomycin, and cisdichlorodiammineplatinum(II). Cancer Treat. Rep. 1979, 63, 1005-1006.

135. Yang, V.; Gouveia, M.J.; Santos, J.; Koksch, B.; Amorim, I.; Gärtner, F.; Vale, N. Breast cancer: Insights in disease and influence of drug methotrexate. RSC Med. Chem. 2020, 11, 646-664. [CrossRef] [PubMed]

136. Neijstrom, E.S.; Capizzi, R.L.; Rudnick, S.A.; Kirsch, M.; Delaney, D.; Kahn, L.; Lipper, S.; Carney, C. High-dose methotrexate in small cell lung cancer: Lack of efficacy in preventing CNS relapse. Cancer 1983, 51, 1056-1061. [CrossRef]

137. Woods, R.L.; Fox, R.M.; Tattersall, M.H. Methotrexate treatment of squamous-cell head and neck cancers: Dose-response evaluation. BMJ 1981, 282, 600-602. [CrossRef] [PubMed] 
138. Sakura, T.; for the Japan Adult Leukemia Study Group (JALSG); Hayakawa, F.; Sugiura, I.; Murayama, T.; Imai, K.; Usui, N.; Fujisawa, S.; Yamauchi, T.; Yujiri, T.; et al. High-dose methotrexate therapy significantly improved survival of adult acute lymphoblastic leukemia: A phase III study by JALSG. Leukemia 2017, 32, 626-632. [CrossRef] [PubMed]

139. Rajagopalan, P.T.R.; Zhang, Z.; McCourt, L.; Dwyer, M.; Benkovic, S.J.; Hammes, G.G. Interaction of dihydrofolate reductase with methotrexate: Ensemble and single-molecule kinetics. Proc. Natl. Acad. Sci. USA 2002, 99, 13481-13486. [CrossRef]

140. Municio, C.; Palacios, B.S.; Estrada-Capetillo, L.; Benguria, A.; Dopazo, A.; García-Lorenzo, E.; Fernández-Arroyo, S.; Joven, J.; Miranda-Carús, M.E.; González-Álvaro, I.; et al. Methotrexate selectively targets human proinflammatory macrophages through a thymidylate synthase/p53 axis. Ann. Rheum. Dis. 2016, 75, 2157-2165. [CrossRef]

141. Golan, T.; Hammel, P.; Reni, M.; Van Cutsem, E.; Macarulla, T.; Hall, M.J.; Park, J.-O.; Hochhauser, D.; Arnold, D.; Oh, D.-Y.; et al. Maintenance Olaparib for Germline BRCA-Mutated Metastatic Pancreatic Cancer. N. Engl. J. Med. 2019, 381, 317-327. [CrossRef] [PubMed]

142. De Bono, J.S.; Mateo, J.; Fizazi, K.; Saad, F.; Shore, N.; Sandhu, S.; Chi, K.N.; Sartor, O.; Agarwal, N.; Olmos, D.; et al. Olaparib for Metastatic Castration-Resistant Prostate Cancer. N. Engl. J. Med. 2020, 382, 2091-2102. [CrossRef] [PubMed]

143. Caulfield, S.E.; Davis, C.C.; Byers, K.F. Olaparib: A Novel Therapy for Metastatic Breast Cancer in Patients With a BRCA1/2 Mutation. J. Adv. Pract. Oncol. 2019, 10, 167-174.

144. Dziadkowiec, K.N.; Gassiorowska, E.; Nowak-Markwitz, E.; Jankowska, A. PARP inhibitors: Review of mechanisms of action and BRCA1/2 mutation targeting. Menopausal Rev. 2016, 15, 215-219. [CrossRef]

145. Wu, Q.; Allouch, A.; Paoletti, A.; Leteur, C.; Mirjolet, C.; Martins, I.; Voisin, L.; Law, F.; Dakhli, H.; Mintet, E.; et al. NOX2dependent ATM kinase activation dictates pro-inflammatory macrophage phenotype and improves effectiveness to radiation therapy. Cell Death Differ. 2017, 24, 1632-1644. [CrossRef] [PubMed]

146. Snyder, A.R.; Morgan, W.F. Gene expression profiling after irradiation: Clues to understanding acute and persistent responses? Cancer Metastasis Rev. 2004, 23, 259-268. [CrossRef]

147. Bansal, A.; Neuhaus, R.; Izquierdo-Alvarez, E.; Vorholt, D.; Feldkötter, H.; Nolte, H.; Lohneis, P.; Büttner, R.; Krüger, M.; Pallasch, C.P.; et al. ATM-mediated DNA damage response in macrophages primes phagocytosis and immune checkpoint regulation. bioRxiv 2020, arXiv:2020.03.14.987438, 987438. [CrossRef]

148. Pinto, A.T.; Pinto, M.L.; Cardoso, A.P.; Monteiro, C.; Maia, A.F.; Castro, P.; Figueira, R.C.S.; Monteiro, A.; Marques, M.; Mareel, M.; et al. Ionizing radiation modulates human macrophages towards a pro-inflammatory phenotype preserving their pro-invasive and pro-angiogenic capacities. Sci. Rep. 2016, 6, 18765. [CrossRef] [PubMed]

149. Kortylewski, M.; Pal, S.K. The dark side of Toll-like receptor signaling. OncoImmunology 2014, 3, e27894. [CrossRef]

150. Chen, J.; Tian, X.; Mei, Z.; Wang, Y.; Yao, Y.; Zhang, S.; Li, X.; Wang, H.; Zhang, J.; Xie, C. The effect of the TLR9 ligand CpG-oligodeoxynucleotide on the protective immune response to radiation-induced lung fibrosis in mice. Mol. Immunol. 2016, 80, 33-40. [CrossRef]

151. Seifert, L.; Werba, G.; Tiwari, S.; Ly, N.N.G.; Nguy, S.; Alothman, S.; Alqunaibit, D.; Avanzi, A.; Daley, D.; Barilla, R.; et al. Radiation Therapy Induces Macrophages to Suppress T-Cell Responses against Pancreatic Tumors in Mice. Gastroenterology 2016, 150, 1659-1672.e5. [CrossRef]

152. Ayoub, M.; Shinde-Jadhav, S.; Mansure, J.J.; Alvarez, F.; Connell, T.; Seuntjens, J.; Piccirillo, C.A.; Kassouf, W. The immune mediated role of extracellular HMGB1 in a heterotopic model of bladder cancer radioresistance. Sci. Rep. 2019, 9, 6348. [CrossRef] [PubMed]

153. Crittenden, M.R.; Cottam, B.; Savage, T.; Nguyen, C.; Newell, P.; Gough, M.J. Expression of NF-kB p50 in Tumor Stroma Limits the Control of Tumors by Radiation Therapy. PLoS ONE 2012, 7, e39295. [CrossRef] [PubMed]

154. Rovere-Querini, P.; Castiglioni, A. Adjuvant role for cell death during chemo- and radiotherapy of cancer? Expert Rev. Clin. Immunol. 2008, 4, 27-32. [CrossRef] [PubMed]

155. Melcher, A.; Todryk, S.; Hardwick, N.; Ford, M.; Jacobson, M.; Vile, R.G. Tumor immunogenicity is determined by the mechanism of cell death via induction of heat shock protein expression. Nat. Med. 1998, 4, 581-587. [CrossRef]

156. Barsoumian, H.B.; Ramapriyan, R.; Younes, A.I.; Caetano, M.S.; Menon, H.; Comeaux, N.I.; Cushman, T.R.; Schoenhals, J.E.; Cadena, A.P.; Reilly, T.P.; et al. Low-dose radiation treatment enhances systemic antitumor immune responses by overcoming the inhibitory stroma. J. Immunother. Cancer 2020, 8, e000537. [CrossRef]

157. Gong, D.; Shi, W.; Yi, S.-J.; Chen, H.; Groffen, J.; Heisterkamp, N. TGF $\beta$ signaling plays a critical role in promoting alternative macrophage activation. BMC Immunol. 2012, 13, 31. [CrossRef]

158. Moreira, D.; Sampath, S.; Won, H.; White, S.V.; Su, Y.-L.; Alcantara, M.; Wang, C.; Lee, P.P.; Maghami, E.; Massarelli, E.; et al. Myeloid cell-targeted STAT3 inhibition sensitizes head and neck cancers to radiotherapy and T cell-mediated immunity. J. Clin. Investig. 2021, 131. [CrossRef]

159. Kang, T.H.; Mao, C.-P.; Kim, Y.S.; Kim, T.W.; Yang, A.; Lam, B.; Tseng, S.-H.; Farmer, E.; Park, Y.-M.; Hung, C.-F. TLR9 acts as a sensor for tumor-released DNA to modulate anti-tumor immunity after chemotherapy. J. Immunother. Cancer 2019, 7, 260. [CrossRef]

160. Oweida, A.J.; Mueller, A.C.; Piper, M.; Milner, D.; Van Court, B.; Bhatia, S.; Phan, A.; Bickett, T.; Jordan, K.; Proia, T.; et al. Response to radiotherapy in pancreatic ductal adenocarcinoma is enhanced by inhibition of myeloid-derived suppressor cells using STAT3 anti-sense oligonucleotide. Cancer Immunol. Immunother. 2020, 1-12. [CrossRef] 
161. Farhood, B.; Khodamoradi, E.; Hoseini-Ghahfarokhi, M.; Motevaseli, E.; Mirtavoos-Mahyari, H.; Musa, A.E.; Najafi, M. TGF- $\beta$ in radiotherapy: Mechanisms of tumor resistance and normal tissues injury. Pharmacol. Res. 2020, 155, 104745. [CrossRef]

162. Pinto, A.T.; Pinto, M.L.; Velho, S.; Pinto, M.T.; Cardoso, A.P.; Figueira, R.; Monteiro, A.; Marques, M.; Seruca, R.; Barbosa, M.A.; et al. Intricate Macrophage-Colorectal Cancer Cell Communication in Response to Radiation. PLoS ONE 2016, 11, e0160891. [CrossRef] [PubMed]

163. Wang, S.-C.; Yu, C.-F.; Hong, J.-H.; Tsai, C.-S.; Chiang, C.-S. Radiation Therapy-Induced Tumor Invasiveness Is Associated with SDF-1-Regulated Macrophage Mobilization and Vasculogenesis. PLoS ONE 2013, 8, e69182. [CrossRef]

164. Kalbasi, A.; Komar, C.; Tooker, G.M.; Liu, M.; Lee, J.W.; Gladney, W.L.; Ben-Josef, E.; Beatty, G.L. Tumor-Derived CCL2 Mediates Resistance to Radiotherapy in Pancreatic Ductal Adenocarcinoma. Clin. Cancer Res. 2017, 23, 137-148. [CrossRef]

165. Shiao, S.L.; Ruffell, B.; DeNardo, D.G.; Faddegon, B.A.; Park, C.C.; Coussens, L.M. TH2-Polarized CD4+ T Cells and Macrophages Limit Efficacy of Radiotherapy. Cancer Immunol. Res. 2015, 3, 518-525. [CrossRef] [PubMed]

166. Stary, V.; Wolf, B.; Unterleuthner, D.; List, J.; Talic, M.; Längle, J.; Beer, A.; Strobl, J.; Stary, G.; Dolznig, H.; et al. Short-course radiotherapy promotes pro-inflammatory macrophages via extracellular vesicles in human rectal cancer. J. Immunother. Cancer 2020, 8, e000667. [CrossRef] [PubMed]

167. DeNardo, D.G.; Brennan, D.J.; Rexhepaj, E.; Ruffell, B.; Shiao, S.L.; Madden, S.F.; Gallagher, W.M.; Wadhwani, N.; Keil, S.D.; Junaid, S.A.; et al. Leukocyte Complexity Predicts Breast Cancer Survival and Functionally Regulates Response to Chemotherapy. Cancer Discov. 2011, 1, 54-67. [CrossRef]

168. Klug, F.; Prakash, H.; Huber, P.E.; Seibel, T.; Bender, N.; Halama, N.; Pfirschke, C.; Voss, R.H.; Timke, C.; Umansky, L.; et al. Low-Dose Irradiation Programs Macrophage Differentiation to an iNOS+/M1 Phenotype that Orchestrates Effective T Cell Immunotherapy. Cancer Cell 2013, 24, 589-602. [CrossRef]

169. De Sousa, J.R.; Vasconcelos, P.F.D.C.; Quaresma, J.A.S. Functional aspects, phenotypic heterogeneity, and tissue immune response of macrophages in infectious diseases. Infect. Drug Resist. 2019, 12, 2589-2611. [CrossRef] [PubMed]

170. Prakash, H.; Klug, F.; Nadella, V.; Mazumdar, V.; Schmitz-Winnenthal, H.; Umansky, L. Low doses of gamma irradiation potentially modifies immunosuppressive tumor microenvironment by retuning tumor-associated macrophages: Lesson from insulinoma. Carcinogenesis 2016, 37, 301-313. [CrossRef]

171. Nowosielska, E.M.; Cheda, A.; Wrembel-Wargocka, J.; Janiak, M.K. Effect of Low Doses of Low-Let Radiation on the Innate Anti-Tumor Reactions in Radioresistant and Radiosensitive Mice. Dose Response 2012, 10, 500-515. [CrossRef] [PubMed]

172. Coates, P.J.; Rundle, J.K.; Lorimore, S.A.; Wright, E.G. Indirect Macrophage Responses to Ionizing Radiation: Implications for Genotype-Dependent Bystander Signaling. Cancer Res. 2008, 68, 450-456. [CrossRef] [PubMed]

173. Lödermann, B.; Wunderlich, R.; Frey, S.; Schorn, C.; Stangl, S.; Rödel, F.; Keilholz, L.; Fietkau, R.; Gaipl, U.S.; Frey, B. Low dose ionising radiation leads to a NF- $\kappa B$ dependent decreased secretion of active IL-1 $\beta$ by activated macrophages with a discontinuous dose-dependency. Int. J. Radiat. Biol. 2012, 88, 727-734. [CrossRef]

174. Vallabhapurapu, S.; Karin, M. Regulation and Function of NF-кB Transcription Factors in the Immune System. Annu. Rev. Immunol. 2009, 27, 693-733. [CrossRef]

175. Greten, F.R.; Eckmann, L.; Greten, T.F.; Park, J.M.; Li, Z.-W.; Egan, L.J.; Kagnoff, M.F.; Karin, M. IKK $\beta$ Links Inflammation and Tumorigenesis in a Mouse Model of Colitis-Associated Cancer. Cell 2004, 118, 285-296. [CrossRef] [PubMed]

176. Pikarsky, E.; Porat, R.M.; Stein, I.; Abramovitch, R.; Amit, S.; Kasem, S.; Gutkovich-Pyest, E.; Urieli-Shoval, S.; Galun, E.; Ben-Neriah, Y. NF- $\mathrm{kB}$ functions as a tumour promoter in inflammation-associated cancer. Nature 2004, 431, 461-466. [CrossRef] [PubMed]

177. Mieczkowski, J.; Kocyk, M.; Nauman, P.; Gabrusiewicz, K.; Sielska, M.; Przanowski, P.; Maleszewska, M.; Rajan, W.D.; Pszczolkowska, D.; Tykocki, T.; et al. Down-regulation of IKK $\beta$ expression in glioma-infiltrating microglia/macrophages is associated with defective inflammatory/immune gene responses in glioblastoma. Oncotarget 2015, 6, 33077-33090. [CrossRef] [PubMed]

178. Porta, C.; Rimoldi, M.; Raes, G.; Brys, L.; Ghezzi, P.; Di Liberto, D.; Dieli, F.; Ghisletti, S.; Natoli, G.; De Baetselier, P.; et al. Tolerance and M2 (alternative) macrophage polarization are related processes orchestrated by p50 nuclear factor B. Proc. Natl. Acad. Sci. USA 2009, 106, 14978-14983. [CrossRef]

179. Saccani, A.; Schioppa, T.; Porta, C.; Biswas, S.K.; Nebuloni, M.; Vago, L.; Bottazzi, B.; Colombo, M.P.; Mantovani, A.; Sica, A. p50 Nuclear Factor-кB Overexpression in Tumor-Associated Macrophages Inhibits M1 Inflammatory Responses and Antitumor Resistance. Cancer Res. 2006, 66, 11432-11440. [CrossRef]

180. Hagemann, T.; Lawrence, T.; McNeish, I.; Charles, K.A.; Kulbe, H.; Thompson, R.G.; Robinson, S.C.; Balkwill, F.R. “Re-educating” tumor-associated macrophages by targeting NF-кB. J. Exp. Med. 2008, 205, 1261-1268. [CrossRef] [PubMed]

181. Hernandez, L.; on behalf of the Australian Ovarian Cancer Study Group; Kim, M.K.; Noonan, A.M.; Sagher, E.; Kohlhammer, H.; Wright, G.L.; Lyle, L.T.; Steeg, P.S.; Anver, M.R.; et al. A dual role for Caspase8 and NF- $\mathrm{kB}$ interactions in regulating apoptosis and necroptosis of ovarian cancer, with correlation to patient survival. Cell Death Discov. 2015, 1, 15053. [CrossRef] [PubMed]

182. Kostova, I.; Mandal, R.; Becker, S.; Strebhardt, K. The role of caspase-8 in the tumor microenvironment of ovarian cancer. Cancer Metastasis Rev. 2021, 40, 303-318. [CrossRef]

183. Verzella, D.; Pescatore, A.; Capece, D.; Vecchiotti, D.; Ursini, M.V.; Franzoso, G.; Alesse, E.; Zazzeroni, F. Life, death, and autophagy in cancer: NF-kB turns up everywhere. Cell Death Dis. 2020, 11, 210. [CrossRef] 
184. Fiore, A.; Ugel, S.; De Sanctis, F.; Sandri, S.; Fracasso, G.; Trovato, R.; Sartoris, S.; Solito, S.; Mandruzzato, S.; Vascotto, F.; et al. Induction of immunosuppressive functions and NF-kB by FLIP in monocytes. Nat. Commun. 2018, 9, 5193. [CrossRef] [PubMed]

185. Fan, Y.; Mao, R.; Yang, J. NF-kB and STAT3 signaling pathways collaboratively link inflammation to cancer. Protein Cell 2013, 4, 176-185. [CrossRef] [PubMed]

186. Liu, J.; Zhou, F.; Chen, Q.; Kang, A.; Lu, M.; Liu, W.; Zang, X.; Wang, G.; Zhang, J. Chronic inflammation up-regulates P-gp in peripheral mononuclear blood cells via the STAT3/Nf-kb pathway in 2,4,6-trinitrobenzene sulfonic acid-induced colitis mice. Sci. Rep. 2015, 5, 13558. [CrossRef]

187. Martincuks, A.; Andryka, K.; Küster, A.; de Leur, H.S.-V.; Komorowski, M.; Müller-Newen, G. Nuclear translocation of STAT3

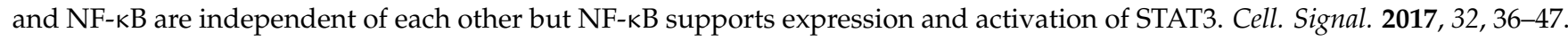
[CrossRef]

188. Yao, Z.; Zhang, J.; Zhang, B.; Liang, G.; Chen, X.; Yao, F.; Xu, X.; Wu, H.; He, Q.; Ding, L.; et al. Imatinib prevents lung cancer metastasis by inhibiting M2-like polarization of macrophages. Pharmacol. Res. 2018, 133, 121-131. [CrossRef]

189. Lee, E.-J.; Lee, S.J.; Kim, J.-H.; Kim, K.-J.; Yang, S.-H.; Jeong, K.-Y.; Seong, J. Radiation Inhibits Interleukin-12 Produc-tion via Inhibition of C-Rel through the Interleukin-6/ Signal Transducer and Activator of Transcription 3 Signaling Pathway in Dendritic Cells. PLOS ONE 2016, 11, e0146463.

190. Xiao, X.; Luo, H.; Vanek, K.N.; LaRue, A.C.; Schulte, B.A.; Wang, G.Y. Catalase Inhibits Ionizing Radiation-Induced Apoptosis in Hematopoietic Stem and Progenitor Cells. Stem Cells Dev. 2015, 24, 1342-1351. [CrossRef]

191. Genard, G.; Lucas, S.; Michiels, C. Reprogramming of Tumor-Associated Macrophages with Anticancer Therapies: Radiotherapy versus Chemo- and Immunotherapies. Front. Immunol. 2017, 8, 828. [CrossRef] [PubMed]

192. Takaoka, A.; Tamura, T.; Taniguchi, T. Interferon regulatory factor family of transcription factors and regulation of oncogenesis. Cancer Sci. 2008, 99, 467-478. [CrossRef] [PubMed]

193. Twum, D.Y.; Colligan, S.H.; Hoffend, N.C.; Katsuta, E.; Gomez, E.C.; Hensen, M.L.; Seshadri, M.; Nemeth, M.J.; Abrams, S.I. IFN regulatory factor-8 expression in macrophages governs an antimetastatic program. JCI Insight 2019, 4, 4. [CrossRef]

194. Tarassishin, L.; Suh, H.-S.; Lee, S.C. Interferon regulatory factor 3 plays an anti-inflammatory role in microglia by activating the PI3K/Akt pathway. J. Neuroinflamm. 2011, 8, 187. [CrossRef]

195. Nixon, B.; Kuo, F.; Liu, M.; Capistrano, K.; Do, M.; Franklin, R.; Wu, X.; Kansler, E.; Srivastava, R.; Purohit, T.; et al. IRF8 Governs Tumor-Associated Macrophage Control of T Cell Exhaustion. SSRN Electron. J. 2020. [CrossRef]

196. Liu, B.; Wang, X.; Chen, T.-Z.; Li, G.-L.; Tan, C.-C.; Chen, Y.; Duan, S.-Q. Polarization of M1 tumor associated macrophage promoted by the activation of TLR3 signal pathway. Asian Pac. J. Trop. Med. 2016, 9, 484-488. [CrossRef] [PubMed]

197. Satoh, T.; Takeuchi, O.; Vandenbon, A.; Yasuda, K.; Tanaka, Y.; Kumagai, Y.; Miyake, T.; Matsushita, K.; Okazaki, T.; Saitoh, T.; et al. The Jmjd3-Irf4 axis regulates M2 macrophage polarization and host responses against helminth infection. Nat. Immunol. 2010, 11, 936-944. [CrossRef] [PubMed]

198. Su, C.; Fu, X.; Duan, W.; Yu, P.; Zhao, Y. High density of CD68+ tumor-associated macrophages predicts a poor prognosis in gastric cancer mediated by IL-6 expression. Oncol. Lett. 2018, 15, 6217-6224. [CrossRef]

199. Zhang, F.; Parayath, N.N.; Ene, C.I.; Stephan, S.B.; Koehne, A.L.; Coon, M.E.; Holland, E.C.; Stephan, M.T. Genetic programming of macrophages to perform anti-tumor functions using targeted mRNA nanocarriers. Nat. Commun. 2019, 10, 1-16. [CrossRef]

200. Galietti, F.; Bollo, E.; Cappia, S.; Dondo, A.; Pregel, P.; Nicali, R.; Pozzi, E. p53 expression in cultured blood human monocytes infected with mycobacterial strains. Panminerva Med. 2001, 43, 249-255.

201. Matas, D.; Milyavsky, M.; Shats, I.; Nissim, L.; Goldfinger, N.; Rotter, V. p53 is a regulator of macrophage differentiation. Cell Death Differ. 2004, 11, 458-467. [CrossRef]

202. Mikhalkevich, N.; O'Carroll, I.P.; Tkavc, R.; Lund, K.; Sukumar, G.; Dalgard, C.L.; Johnson, K.R.; Li, W.; Wang, T.; Nath, A.; et al. Response of human macrophages to gamma radiation is mediated via expression of endogenous retro-viruses. PLoS Pathog. 2021, 17, e1009305. [CrossRef]

203. Lowe, J.M.; Menendez, D.; Fessler, M.B. A new inflammatory role for p53 in human macrophages. Cell Cycle 2014, 13, $2983-2984$. [CrossRef]

204. Murphy, S.H.; Suzuki, K.; Downes, M.; Welch, G.L.; De Jesus, P.; Miraglia, L.J.; Orth, A.P.; Chanda, S.K.; Evans, R.M.; Verma, I.M. Tumor suppressor protein (p)53, is a regulator of NF- B repression by the glucocorticoid receptor. Proc. Natl. Acad. Sci. USA 2011, 108, 17117-17122. [CrossRef] [PubMed]

205. An, Y.; Yang, Q. MiR-21 modulates the polarization of macrophages and increases the effects of M2 macrophages on promoting the chemoresistance of ovarian cancer. Life Sci. 2020, 242, 117162. [CrossRef] [PubMed]

206. Saliba, D.G.; Heger, A.; Eames, H.L.; Oikonomopoulos, S.; Teixeira, A.; Blazek, K.; Androulidaki, A.; Wong, D.; Goh, F.G.; Weiss, M.; et al. IRF5:RelA Interaction Targets Inflammatory Genes in Macrophages. Cell Rep. 2014, 8, 1308-1317. [CrossRef] [PubMed]

207. Ishikawa, H.; Ma, Z.; Barber, G.N. STING regulates intracellular DNA-mediated, type I interferon-dependent innate immunity. Nat. Cell Biol. 2009, 461, 788-792. [CrossRef]

208. Merched, A.J.; Williams, E.; Chan, L. Macrophage-Specific p53 Expression Plays a Crucial Role in Atherosclerosis Development and Plaque Remodeling. Arter. Thromb. Vasc. Biol. 2003, 23, 1608-1614. [CrossRef]

209. Zheng, S.-J.; Lamhamedi-Cherradi, S.-E.; Wang, P.; Xu, L.; Chen, Y.H. Tumor Suppressor p53 Inhibits Autoimmune Inflammation and Macrophage Function. Diabetes 2005, 54, 1423-1428. [CrossRef] 
210. He, X.-Y.; Xiang, C.; Zhang, C.-X.; Xie, Y.-Y.; Chen, L.; Zhang, G.-X.; Lu, Y.; Liu, G. p53 in the Myeloid Lineage Modulates an Inflammatory Microenvironment Limiting Initiation and Invasion of Intestinal Tumors. Cell Rep. 2015, 13, 888-897. [CrossRef] [PubMed]

211. Lowe, J.M.; Menendez, D.; Bushel, P.R.; Shatz, M.; Kirk, E.L.; Troester, M.A.; Garantziotis, S.; Fessler, M.B.; Resnick, M.A. p53 and NF-кB Coregulate Proinflammatory Gene Responses in Human Macrophages. Cancer Res. 2014, 74, 2182-2192. [CrossRef]

212. Lim, Y.-J.; Lee, J.; Choi, J.-A.; Cho, S.-N.; Son, S.-H.; Kwon, S.-J.; Son, J.-W.; Song, C.-H. M1 macrophage dependent-p53 regulates the intracellular survival of mycobacteria. Apoptosis 2020, 25, 42-55. [CrossRef]

213. Rackov, G.; Hernández-Jiménez, E.; Shokri, R.; Carmona-Rodríguez, L.; Mañes, S.; Álvarez-Mon, M.; López-Collazo, E.; Martínez-A, C.; Balomenos, D. p21 mediates macrophage reprogramming through regulation of p50-p50 NF- $\mathrm{kB}$ and IFN- $\beta$ J. Clin. Investig. 2016, 126, 3089-3103. [CrossRef] [PubMed]

214. Guan, H.; Hou, S.; Ricciardi, R.P. DNA Binding of Repressor Nuclear Factor- $\kappa B$ p50/p50 Depends on Phosphorylation of Ser337 by the Protein Kinase A Catalytic Subunit. J. Biol. Chem. 2005, 280, 9957-9962. [CrossRef]

215. Li, Y.; Weng, Y.; Zhong, L.; Chong, H.; Chen, S.; Sun, Y.; Li, W.; Shi, Q. VEGFR3 inhibition chemosensitizes lung adenocarcinoma A549 cells in the tumor-associated macrophage microenvironment through upregulation of p53 and PTEN. Oncol. Rep. 2017, 38, 2761-2773. [CrossRef] [PubMed]

216. Fang, D.D.; Tang, Q.; Kong, Y.; Wang, Q.; Gu, J.; Fang, X.; Zou, P.; Rong, T.; Wang, J.; Yang, D.; et al. MDM2 inhibitor APG-115 synergizes with PD-1 blockade through enhancing antitumor immunity in the tumor microenvironment. J. Immunother. Cancer 2019, 7, 1-16. [CrossRef] [PubMed]

217. Izquierdo, E.; Vorholt, D.; Sackey, B.; Nolte, J.L.; Blakemore, S.; Schmitz, J.; Barbarino, V.; Nickel, N.; Bachurski, D.; Lobastova, L.; et al. Loss of TP53 mediates suppression of Macrophage Effector Function via Extracellular Vesicles and PDL1 towards Resistance against Chemoimmunotherapy in B-cell malignancies. bioRxiv 2020. [CrossRef]

218. Lorimore, S.A.; Rastogi, S.; Mukherjee, D.; Coates, P.J.; Wright, E.G. The Influence of p53 Functions on Radiation-Induced Inflammatory Bystander-Type Signaling in Murine Bone Marrow. Radiat. Res. 2013. [CrossRef]

219. Kang, J.-H.; Woo, J.K.; Jang, Y.-S.; Oh, S.H. Radiation Potentiates Monocyte Infiltration into Tumors by Ninjurin1 Expression in Endothelial Cells. Cells 2020, 9, 1086. [CrossRef]

220. Yoshino, H.; Konno, H.; Ogura, K.; Sato, Y.; Kashiwakura, I. Relationship between the Regulation of Caspase-8-Mediated Apoptosis and Radioresistance in Human THP-1-Derived Macrophages. Int. J. Mol. Sci. 2018, 19, 3154. [CrossRef]

221. Tabraue, C.; Lara, P.C.; De Mirecki-Garrido, M.; De La Rosa, J.V.; López-Blanco, F.; Fernández-Pérez, L.; Boscá, L.; Castrillo, A. LXR Signaling Regulates Macrophage Survival and Inflammation in Response to Ionizing Radiation. Int. J. Radiat. Oncol. 2019, 104, 913-923. [CrossRef]

222. Kamran, S.C.; Lennerz, J.K.; Margolis, C.A.; Liu, D.; Reardon, B.; Wankowicz, S.A.; Van Seventer, E.E.; Tracy, A.; Wo, J.Y.; Carter, S.L.; et al. Integrative Molecular Characterization of Resistance to Neoadjuvant Chemoradiation in Rectal Cancer. Clin. Cancer Res. 2019, 25, 5561-5571. [CrossRef]

223. Ahmed, S.M.U.; Luo, L.; Namani, A.; Wang, X.J.; Tang, X. Nrf2 signaling pathway: Pivotal roles in inflammation. Biochim. et Biophys. Acta (BBA) Mol. Basis Dis. 2017, 1863, 585-597. [CrossRef] [PubMed]

224. Feng, R.; Morine, Y.; Ikemoto, T.; Imura, S.; Iwahashi, S.; Saito, Y.; Shimada, M. Nrf2 activation drive macrophages polarization and cancer cell epithelial-mesenchymal transition during interaction. Cell Commun. Signal. 2018, 16, 1-12. [CrossRef]

225. Ji, Y.; Studzinski, G.P. Retinoblastoma Protein and CCAAT/Enhancer-Binding Protein $\beta$ Are Required for 1,25-Dihydroxyvitamin D3-Induced Monocytic Differentiation of HL60 Cells. Cancer Res. 2004, 64, 370-377. [CrossRef] [PubMed]

226. Satoh, H.; Moriguchi, T.; Taguchi, K.; Takai, J.; Maher, J.M.; Suzuki, T.; Winnard, P.T., Jr.; Raman, V.; Ebina, M.; Nukiwa, T.; et al. Nrf2-deficiency creates a responsive microenvironment for metastasis to the lung. Carcinogenesis 2010, 31, 1833-1843. [CrossRef] [PubMed]

227. Kobayashi, E.; Suzuki, T.; Yamamoto, M. Roles Nrf2 Plays in Myeloid Cells and Related Disorders. Oxidative Med. Cell. Longev. 2013, 2013, 1-7. [CrossRef]

228. Tsukimoto, M.; Tamaishi, N.; Homma, T.; Kojima, S. Low-Dose Gamma-Ray Irradiation Induces Translocation of Nrf2 into Nuclear in Mouse Macrophage RAW264.7 Cells. J. Radiat. Res. 2010, 51, 349-353. [CrossRef]

229. Wang, P.; Geng, J.; Gao, J.; Zhao, H.; Li, J.; Shi, Y.; Yang, B.; Xiao, C.; Linghu, Y.; Sun, X.; et al. Macrophage achieves self-protection against oxidative stress-induced ageing through the Mst-Nrf2 axis. Nat. Commun. 2019, 10, 1-16. [CrossRef]

230. Saha, S.; Buttari, B.; Panieri, E.; Profumo, E.; Saso, L. An Overview of Nrf2 Signaling Pathway and Its Role in Inflammation. Molecules 2020, 25, 5474. [CrossRef]

231. Shu, Y.; Qin, M.; Song, Y.; Tang, Q.; Huang, Y.; Shen, P.; Lu, Y. M2 polarization of tumor-associated macrophages is dependent on integrin $\beta 3$ via peroxisome proliferator-activated receptor- $\gamma$ up-regulation in breast cancer. Immunology 2020, 160, 345-356. [CrossRef]

232. Cheng, W.Y.; Huynh, H.; Chen, P.; Peña-Llopis, S.; Wan, Y. Macrophage PPAR $\gamma$ inhibits Gpr132 to mediate the anti-tumor effects of rosiglitazone. eLife 2016, 5, 557. [CrossRef]

233. Kim, Y.-B.; Ahn, Y.-H.; Jung, J.-H.; Lee, Y.-J.; Lee, J.-H.; Kang, J.L. Programming of macrophages by UV-irradiated apoptotic cancer cells inhibits cancer progression and lung metastasis. Cell. Mol. Immunol. 2019, 16, 851-867. [CrossRef] 
234. Gionfriddo, G.; Plastina, P.; Augimeri, G.; Catalano, S.; Giordano, C.; Barone, I.; Morelli, C.; Giordano, F.; Gelsomino, L.; Sisci, D.; et al. Modulating Tumor-Associated Macrophage Polarization by Synthetic and Natural PPAR $\gamma$ Ligands as a Potential Target in Breast Cancer. Cells 2020, 9, 174. [CrossRef] [PubMed]

235. Bradley, M.N.; Zhou, L.; Smale, S.T. C/EBP $\beta$ Regulation in Lipopolysaccharide-Stimulated Macrophages. Mol. Cell. Biol. 2003, 23, 4841-4858. [CrossRef] [PubMed]

236. Screpanti, I.; Romani, L.; Musiani, P.; Modesti, A.; Fattori, E.; Lazzaro, D.; Sellitto, C.; Scarpa, S.; Bellavia, D.; Lattanzio, G. Lymphoproliferative disorder and imbalanced T-helper response in C/EBP beta-deficient mice. EMBO J. 1995, 14, 1932-1941. [CrossRef] [PubMed]

237. Ruffell, D.; Mourkioti, F.; Gambardella, A.; Kirstetter, P.; Lopez, R.G.; Rosenthal, N.; Nerlov, C. A CREB-C/EBP cascade induces M2 macrophage-specific gene expression and promotes muscle injury repair. Proc. Natl. Acad. Sci. USA 2009, 106, 17475-17480. [CrossRef] [PubMed]

238. Luft, F.C. C/EBP $\beta$ LIP induces a tumor menagerie making it an oncogene. J. Mol. Med. 2014, 93, 1-3. [CrossRef] [PubMed]

239. Ollivier, V.; Parry, G.C.; Cobb, R.R.; de Prost, D.; Mackman, N. Elevated Cyclic AMP Inhibits NF-kB-mediated Transcription in Human Monocytic Cells and Endothelial Cells. J. Biol. Chem. 1996, 271, 20828-20835. [CrossRef] [PubMed]

240. Parry, G.C.; Mackman, N. Role of cyclic AMP response element-binding protein in cyclic AMP inhibition of NF-kappaB-mediated transcription. J. Immunol. 1997, 159, 5450-5456. [PubMed]

241. Shankar, D.B.; Cheng, J.C.; Kinjo, K.; Federman, N.; Moore, T.B.; Gill, A.; Rao, N.P.; Landaw, E.M.; Sakamoto, K.M. The role of CREB as a proto-oncogene in hematopoiesis and in acute myeloid leukemia. Cancer Cell 2005, 7, 351-362. [CrossRef]

242. Tugal, D.; Liao, X.; Jain, M.K. Transcriptional Control of Macrophage Polarization. Arterioscler. Thromb. Vasc. Biol. 2013, 33, 1135-1144. [CrossRef] [PubMed]

243. Koschmieder, S.; Agrawal, S.; Radomska, S.H.; Huettner, S.C.; Tenen, G.D.; Ottmann, G.O.; Berdel, E.W.; Serve, L.H.; MüllerTidow, C. Decitabine and Vitamin D3 differentially affect hematopoietic transcription factors to induce monocytic differentiation. Int. J. Oncol. 2007, 30, 349-355. [CrossRef] [PubMed]

244. Smink, J.J.; Leutz, A. Rapamycin and the transcription factor C/EBP $\beta$ as a switch in osteoclast differentiation: Implications for lytic bone diseases. J. Mol. Med. 2009, 88, 227-233. [CrossRef]

245. Nakahara, T.; Morita, A.; Yagasaki, R.; Mori, A.; Sakamoto, K. Mammalian Target of Rapamycin (mTOR) as a Potential Therapeutic Target in Pathological Ocular Angiogenesis. Biol. Pharm. Bull. 2017, 40, 2045-2049. [CrossRef] [PubMed]

246. Rojas, A.; Delgado-López, F.; Perez-Castro, R.; Gonzalez, I.; Romero, J.; Rojas, I.; Araya, P.; Añazco, C.; Morales, E.; Llanos, J. HMGB1 enhances the protumoral activities of M2 macrophages by a RAGE-dependent mechanism. Tumor Biol. 2016, 37, 3321-3329. [CrossRef]

247. Zhang, W.; Tian, J.; Hao, Q. HMGB1 combining with tumor-associated macrophages enhanced lymphangiogenesis in human epithelial ovarian cancer. Tumor Biol. 2014, 35, 2175-2186. [CrossRef] [PubMed]

248. Liao, Y.; Liu, S.; Fu, S.; Wu, J. HMGB1 in Radiotherapy: A Two Headed Signal Regulating Tumor Radiosensitivity and Immunity. OncoTargets Ther. 2020, 13, 6859-6871. [CrossRef] [PubMed]

249. Apetoh, L.; Ghiringhelli, F.; Tesniere, A.; Criollo, A.; Ortiz, C.; Lidereau, R.; Mariette, C.; Chaput, N.; Mira, J.-P.; Delaloge, S.; et al. The interaction between HMGB1 and TLR4 dictates the outcome of anticancer chemotherapy and radiotherapy. Immunol. Rev. 2007, 220, 47-59. [CrossRef]

250. Liu, M.; Tong, Z.; Ding, C.; Luo, F.; Wu, S.; Wu, C.; Albeituni, S.; He, L.; Hu, X.; Tieri, D.; et al. Transcription factor c-Maf is a checkpoint that programs macrophages in lung cancer. J. Clin. Investig. 2020, 130, 2081-2096. [CrossRef] [PubMed]

251. Yadav, M.K.; Inoue, Y.; Nakane-Otani, A.; Tsunakawa, Y.; Jeon, H.; Samir, O.; Teramoto, A.; Kulathunga, K.; Kusakabe, M.; Nakamura, M.; et al. Transcription factor MafB is a marker of tumor-associated macrophages in both mouse and humans. Biochem. Biophys. Res. Commun. 2020, 521, 590-595. [CrossRef] [PubMed]

252. Daassi, D.; Hamada, M.; Jeon, H.; Imamura, Y.; Tran, M.T.N.; Takahashi, S. Differential expression patterns of MafB and c-Maf in macrophages in vivo and in vitro. Biochem. Biophys. Res. Commun. 2016, 473, 118-124. [CrossRef] [PubMed]

253. Fontana, M.F.; Baccarella, A.; Pancholi, N.; Pufall, M.A.; Herbert, D.R.; Kim, C.C. JUNB Is a Key Transcriptional Modulator of Macrophage Activation. J. Immunol. 2015, 194, 177-186. [CrossRef] [PubMed]

254. Bartish, M.; Tong, D.; Pan, Y.; Wallerius, M.; Liu, H.; Ristau, J.; Ferreira, S.D.S.; Wallmann, T.; Van Hoef, V.; Masvidal, L.; et al. MNK2 governs the macrophage antiinflammatory phenotype. Proc. Natl. Acad. Sci. USA 2020, 117, 27556-27565. [CrossRef]

255. Rocco, D.; Della Gravara, L.; Battiloro, C.; Gridelli, C. The role of combination chemo-immunotherapy in advanced non-small cell lung cancer. Expert Rev. Anticancer. Ther. 2019, 19, 561-568. [CrossRef]

256. Vera Aguilera, J.; Paludo, J.; McWilliams, R.R.; Zhang, H.; Li, Y.; Kumar, A.B.; Failing, J.; Kottschade, L.A.; Block, M.S.; Markovic, S.N.; et al. Chemo-immunotherapy combination after PD-1 inhibitor failure improves clinical outcomes in metastatic melanoma patients. Melanoma Res. 2020, 30, 364-375. [CrossRef]

257. Ma, Y.; Adjemian, S.; Mattarollo, S.R.; Yamazaki, T.; Aymeric, L.; Yang, H.; Catani, J.P.P.; Hannani, D.; Duret, H.; Steegh, K.; et al. Anticancer Chemotherapy-Induced Intratumoral Recruitment and Differentiation of Antigen-Presenting Cells. Immun. 2013, 38, 729-741. [CrossRef]

258. Xiao, H.; Guo, Y.; Li, B.; Li, X.; Wang, Y.; Han, S.; Cheng, D.; Shuai, X. M2-Like Tumor-Associated Macrophage-Targeted Codelivery of STAT6 Inhibitor and IKK $\beta$ siRNA Induces M2-to-M1 Repolarization for Cancer Immunotherapy with Low Immune Side Effects. ACS Central Sci. 2020, 6, 1208-1222. [CrossRef] 
259. De Silva, S.; Fromm, G.; Shuptrine, C.W.; Johannes, K.; Patel, A.; Yoo, K.J.; Huang, K.; Schreiber, T.H. CD40 Enhances Type I Interferon Responses Downstream of CD47 Blockade, Bridging Innate and Adaptive Immunity. Cancer Immunol. Res. 2019, 8 , 230-245. [CrossRef]

260. Cabrales, P. RRx-001 Acts as a Dual Small Molecule Checkpoint Inhibitor by Downregulating CD47 on Cancer Cells and SIRP- $\alpha$ on Monocytes/Macrophages. Transl. Oncol. 2019, 12, 626-632. [CrossRef]

261. Ring, N.G.; Herndler-Brandstetter, D.; Weiskopf, K.; Shan, L.; Volkmer, J.-P.; George, B.M.; Lietzenmayer, M.; McKenna, K.M.; Naik, T.J.; Mccarty, A.; et al. Anti-SIRP $\alpha$ antibody immunotherapy enhances neutrophil and macrophage antitumor activity. Proc. Natl. Acad. Sci. USA 2017, 114, E10578-E10585. [CrossRef] [PubMed]

262. Li, X.; Bu, W.; Meng, L.; Liu, X.; Wang, S.; Jiang, L.; Ren, M.; Fan, Y.; Sun, H. CXCL12/CXCR4 pathway orchestrates CSC-like properties by CAF recruited tumor associated macrophage in OSCC. Exp. Cell Res. 2019, 378, 131-138. [CrossRef] [PubMed]

263. Nywening, T.M.; Wang-Gillam, A.; Sanford, D.E.; Belt, B.A.; Panni, R.Z.; Cusworth, B.M.; Toriola, A.T.; Nieman, R.K.; Worley, L.A.; Yano, M.; et al. Targeting tumour-associated macrophages with CCR2 inhibition in combination with FOLFIRINOX in patients with borderline resectable and locally advanced pancreatic cancer: A single-centre, open-label, dose-finding, non-randomised, phase $1 \mathrm{~b}$ trial. Lancet Oncol. 2016, 17, 651-662. [CrossRef]

264. Yan, D.; Kowal, J.; Akkari, L.; Schuhmacher, A.J.; Huse, J.T.; West, B.L.; Joyce, J.A. Inhibition of colony stimulating factor-1 receptor abrogates microenvironment-mediated therapeutic resistance in gliomas. Oncogene 2017, 36, 6049-6058. [CrossRef] [PubMed]

265. Jones, K.I.; Tiersma, J.; Yuzhalin, A.E.; Gordon-Weeks, A.N.; Buzzelli, J.; Im, J.H.; Muschel, R.J. Radiation combined with macrophage depletion promotes adaptive immunity and potentiates checkpoint blockade. EMBO Mol. Med. 2018, 10, e9342. [CrossRef] [PubMed]

266. Stafford, J.H.; Hirai, T.; Deng, L.; Chernikova, S.B.; Urata, K.; West, B.L.; Brown, J.M. Colony stimulating factor 1 receptor inhibition delays recurrence of glioblastoma after radiation by altering myeloid cell recruitment and polarization. Neuro-Oncology 2016, 18, 797-806. [CrossRef] [PubMed]

267. Stoecklein, V.M.; Osuka, A.; Ishikawa, S.; Lederer, M.R.; Wanke-Jellinek, L.; Lederer, J.A. Radiation Exposure Induces Inflammasome Pathway Activation in Immune Cells. J. Immunol. 2015, 194, 1178-1189. [CrossRef] [PubMed]

268. Chiang, C.-S.; Hong, J.-H.; Wu, Y.C.; McBride, W.H.; Dougherty, G.J. Combining radiation therapy with interleukin-3 gene immunotherapy. Cancer Gene Ther. 2000, 7, 1172-1178. [CrossRef] [PubMed]

269. Li, X.; Gong, Y.; Li, D.; Xiang, L.; Ou, Y.; Jiang, L.; Shu, P.; Liu, X.; Guo, F.; Qin, D.; et al. Low-Dose Radiation Therapy Promotes Radiation Pneumonitis by Activating NLRP3 Inflammasome. Int. J. Radiat. Oncol. 2020, 107, 804-814. [CrossRef]

270. Qin, H.; Wilson, C.A.; Lee, S.J.; Zhao, X.; Benveniste, E.N. LPS induces CD40 gene expression through the activation of NF- $k B$ and STAT- $1 \alpha$ in macrophages and microglia. Blood 2005, 106, 3114-3122. [CrossRef]

271. Chen, H.; Li, M.; Sanchez, E.; Soof, C.M.; Bujarski, S.; Ng, N.; Cao, J.; Hekmati, T.; Zahab, B.; Nosrati, J.D.; et al. JAK1/2 pathway inhibition suppresses M2 polarization and overcomes resistance of myeloma to lenalidomide by reducing TRIB1, MUC1, CD44, CXCL12, and CXCR4 expression. Br. J. Haematol. 2020, 188, 283-294. [CrossRef] [PubMed]

272. Hu, X.; Park-Min, K.-H.; Ho, H.H.; Ivashkiv, L.B. IFN- $\gamma$-Primed Macrophages Exhibit Increased CCR2-Dependent Migration and Altered IFN- $\gamma$ Responses Mediated by Stat1. J. Immunol. 2005, 175, 3637-3647. [CrossRef] [PubMed]

273. Maeda, S.; Kamata, H.; Luo, J.-L.; Leffert, H.; Karin, M. IKK $\beta$ Couples Hepatocyte Death to Cytokine-Driven Compensatory Proliferation that Promotes Chemical Hepatocarcinogenesis. Cell 2005, 121, 977-990. [CrossRef] [PubMed]

274. Li, K.; Lu, L.; Xue, C.; Liu, J.; He, Y.; Zhou, J.; Xia, Z.; Dai, L.; Luo, Z.; Mao, Y.; et al. Polarization of tumor-associated macrophage phenotype via porous hollow iron nanoparticles for tumor immunotherapy in vivo. Nanoscale 2019, 12, 130-144. [CrossRef]

275. Huang, M.; Li, Y.; Wu, K.; Yan, W.; Tian, T.; Wang, Y.; Yang, H. Paraquat modulates microglia M1/M2 polarization via activation of TLR4-mediated NF-kB signaling pathway. Chem. Interact. 2019, 310, 108743. [CrossRef] [PubMed]

276. Chen, D.; Xie, J.; Fiskesund, R.; Dong, W.; Liang, X.; Lv, J.; Jin, X.; Liu, J.; Mo, S.; Zhang, T.; et al. Chloroquine modulates antitumor immune response by resetting tumor-associated macrophages toward M1 phenotype. Nat. Commun. 2018, 9, 873. [CrossRef] [PubMed]

277. De Meyer, I.; Martinet, W.; Schrijvers, D.M.; Timmermans, J.-P.; Bult, H.; De Meyer, G.R.Y. Toll-like receptor 7 stimulation by imiquimod induces macrophage autophagy and inflammation in atherosclerotic plaques. Basic Res. Cardiol. 2012, 107, 1-13. [CrossRef]

278. D'Acquisto, F. Inhibition of Nuclear Factor Kappa B (NF-B): An Emerging Theme in Anti-Inflammatory Therapies. Mol. Interv. 2002, 2, 22-35. [CrossRef] [PubMed]

279. Bowie, A.G.; O'Neill, L.A.J. Vitamin C Inhibits NF-kB Activation by TNF Via the Activation of p38 Mitogen-Activated Protein Kinase. J. Immunol. 2000, 165, 7180-7188. [CrossRef] [PubMed]

280. Orange, J.S.; May, M.J. Cell penetrating peptide inhibitors of Nuclear Factor-kappa B. Cell. Mol. Life Sci. 2008, 65, 3564-3591. [CrossRef] [PubMed]

281. Han, S.-K.; Song, J.-Y.; Yun, Y.-S.; Yi, S.-Y. Effect of gamma radiation on cytokine expression and cytokine-receptor mediated STAT activation. Int. J. Radiat. Biol. 2006, 82, 686-697. [CrossRef] [PubMed]

282. Jia, X.; Yuzhen, W.; Wang, J.; Iwanowycz, S.; Saaoud, F.; Wang, Y.; Hu, J.; Wang, Q.; Fan, D. Emodin suppresses pulmonary metastasis of breast cancer accompanied with decreased macrophage recruitment and M2 polarization in the lungs. Breast Cancer Res. Treat. 2014, 148, 291-302. [CrossRef] [PubMed] 
283. Tariq, M.; Zhang, J.-Q.; Liang, G.-K.; He, Q.-J.; Ding, L.; Yang, B. Gefitinib inhibits M2-like polarization of tumor-associated macrophages in Lewis lung cancer by targeting the STAT6 signaling pathway. Acta Pharmacol. Sin. 2017, 38, 1501-1511. [CrossRef]

284. Binnemars-Postma, K.; Bansal, R.; Storm, G.; Prakash, J. Targeting the Stat6 pathway in tumor-associated macrophages reduces tumor growth and metastatic niche formation in breast cancer. FASEB J. 2018, 32, 969-978. [CrossRef] [PubMed] 